\title{
LA GRAN GUERRA DE LAS MUJERES. EL MUNDO EN 1914 Y LOS ORÍGENES DEL FEMINISMO COSTARRICENSE
}

\begin{abstract}
Dennis Arias Mora*
Resumen: El objetivo de este artículo es determinar el efecto que tuvo la Primera Guerra Mundial (1914-1918) en las esferas política, social y cultural de las mujeres costarricenses de comienzos del siglo XX. Para ello se consideran tres tipos de fuentes documentales: informes diplomáticos, revistas culturales y prensa. De este modo, el artículo analiza, primero, los problemas de estudio aportados por las historiografías internacionales de género y de las mujeres al conocimiento de la Gran Guerra; segundo, se reconstruye el panorama sociopolítico de las mujeres costarricenses en el momento de acontecer la contienda; y tercero, se analizan las distintas repercusiones que tuvo esta guerra en las mujeres tomando en cuenta la imagen de la mujer sobre su participación en la guerra, sus experiencias en esta según residieran en el país o en el continente europeo, sus formas de movilización a distancia y las maneras en que esta participación incidió en la conformación del movimiento feminista de la época.
\end{abstract}

Palabras clave: Primera Guerra Mundial; historia de las mujeres; feminismo; Costa Rica; siglo XX.

Abstract: The objective of this article is to determine the effect that the First World War (1914-1918) had on the political, social and cultural spheres of Costa Rican women at the beginning of the 20th century. For this, three types of documentary sources are considered: diplomatic reports, cultural magazines and press. In this way, the article analyzes, first, the study problems contributed by international historiographies of gender and women to the knowledge of the Great War; second, the socio-political overview of Costa Rican women at the time of the war is reconstructed; and third, it analyzes the different repercussions that this war had on women, taking into account the image of women about their participation in the war, their experiences during it as they lived in the country or on the European

Fecha de recepción: 17/01/2018 - Fecha de aceptación: 24/02/2018

Costarricense. Doctor en Historia por la Universidad Libre de Berlín, Alemania. Profesor en la Escuela de Historia e investigador del Centro de Investigación en Identidad y Cultura Latinoamericanas (CIICLA), de la Universidad de Costa Rica (UCR). Correo electrónico: dennis.arias@ucr.ac.cr 
continent, their forms of distance mobilization and the ways in which this participation affected the shaping of the feminist movement of the time.

Keywords: First World War; Women's History; Feminism; Costa Rica; Twentieth Century.

\section{Introducción y premisas ${ }^{1}$}

La historiografía de las mujeres ha tenido un importante desarrollo en la región centroamericana y en la academia costarricense, ${ }^{2}$ acerca del período analizado en este artículo, en torno a la Primera Guerra Mundial, son abundantes los estudios sobre las mujeres en su vida cotidiana, en el mundo de la filantropía, en actividades obreras, en educación, en movilizaciones sociales, en su participación política partidaria y en su organización sufragista. ${ }^{3}$ La historiografía sobre el impacto de aquella guerra en el país, en cambio, se encuentra menos desarrollada, pero la cercanía de su centenario ha impulsado una valiosa diversidad de aproximaciones que van desde su impacto como primer fenómeno mediático global en la prensa, ${ }^{4}$ hasta las recientes contribuciones sobre los efectos de la guerra en la Iglesia católica y en la producción literaria local, ${ }^{5}$ estudios que se

1 Agradezco a Nasly Madrigal por la importante labor de recopilación documental requerida para la investigación. También doy gracias al Prof. Dr. Stefan Rinke por facilitarme algunas de las fuentes que reunió para su libro sobre la Gran Guerra en América Latina. Este trabajo se publica gracias al apoyo de la Vicerrectoría de Investigación y del Centro de Investigación en Identidad y Cultura Latinoamericanas (CIICLA), de la Universidad de Costa Rica.

2 Un balance riguroso puede verse en Eugenia Rodríguez, "Historia de las mujeres y de género en Costa Rica: avances y desafíos", en: La historiografía costarricense en la primera década del siglo XXI: tendencias, avances e innovaciones, (eds.) David Díaz Arias, Iván Molina Jiménez y Ronny Viales Hurtado (San José, Costa Rica: EUCR, 2014), 223-270.

3 Referencias bibliográficas sobre estos temas podrán verse en el tercer apartado.

4 Patricia Vega Jiménez, "Primicias de la Primera Guerra Mundial en la prensa costarricense (1914)", Intercambio. Revista sobre Centroamérica y el Caribe (Costa Rica) 4, n. 5 (2007): 271-308; Patricia Vega Jiménez, "Guerra, prensa y manipulación informativa. La prensa centroamericana en 1915", Cuadernos Intercambio sobre Centroamérica y el Caribe (Costa Rica) 9, n. 10 (2012): 153-179; Patricia Vega Jiménez, "La guerra como espectáculo mediático. La prensa centroamericana en la Gran Guerra (1917)", Historia y Comunicación Social (España) 18 (2013), 43-61; Enrique Quesada, "Informar la Gran Guerra desde un periódico local: el caso de El Correo del Atlántico (1914-1917)”, Historia y Comunicación Social (España) 18 (2013), 305-321; Javier Agüero, “Costa Rica y la Primera Guerra Mundial: las crónicas periodísticas y las consecuencias del conflicto (1914-1919)”, Boletín AFEHC (Francia) 65 (junio, 2015), URL: http://afehc-historia-centroamericana.org/index.php?action=fi_aff\&id=3993 (Fecha de acceso: 19 de diciembre de 2017); Patricia Vega, "Reflejo mediático centroamericano del final de la Gran Guerra", Boletín AFEHC (Francia) 65 (junio 2015), URL: http://afehc-historia-centroamericana.org/index.php?action=fi aff\&id=4003 (Fecha de acceso: 19 de diciembre de 2017).

5 Esteban Sánchez, "La Iglesia católica y la Primera Guerra Mundial: crisis mundial y sus consecuencias en Costa Rica (1914-1919)", Boletín AFEHC (Francia) 65 (junio, 2015), URL: http://afehc-historia-centroamericana.org/index.php?action=fi_aff\&id=3998 (Fecha de acceso: 19 de diciembre de 2017); Jorge Chen, "La Primera Guerra Mundial y la poesía centroamericana: la contienda vista por José Basileo Acuña y Salomón de la Selva", Pensamiento Actual (Costa Rica) 13, n. 21 (2013): 51-67; Mario Oliva Medina, "Desilusión y esperanzas durante la Gran Guerra: poetas y cronistas americanos", Temas de Nuestra América (Costa Rica) 31, n. 58 (julio-diciembre, 2015): 15-31. 
suman a los ya clásicos sobre las repercusiones en el comercio exterior y, en consecuencia, en el soporte tributario del Estado, en la moneda local y en el abastecimiento para el consumo $;^{6} \mathrm{o}$ sobre el inestable mundo de la política y de las relaciones internacionales. ${ }^{7}$

A pesar del desarrollo de ambas historiografías, la de las mujeres y la de los efectos locales de la Gran Guerra, es notable la separación entre ellas, por lo cual no se conoce la relación entre aquel mundo en guerra y la vida de las mujeres costarricenses; posiblemente ello se deba, y esta es una de las hipótesis de trabajo de este artículo, a la ausencia que tiene la guerra en los recuerdos de las propias mujeres de la época, entre ellas algunas connotadas feministas. Ya se verá por qué pudo haber sido así. La separación entre la historiografía local de las mujeres y la de los efectos de la Gran Guerra en el país resulta más llamativa al determinar los valiosos aportes dados por la historiografía internacional de las mujeres al conocimiento de ese hecho bélico, cuestiones retomadas recientemente dentro de los estudios sobre el caso latinoamericano.

Este artículo recupera algunos de esos aportes, resumidos en el siguiente apartado, para poder establecer algunos problemas de estudio y traducirlos en unas cuantas preguntas concretas. ¿Cómo es la vivencia de la guerra en la experiencia local e internacional de las mujeres costarricenses? ¿De qué manera se proyectan asuntos determinantes del liberalismo de la época para la inserción de las mujeres al espacio público -educación, maternidad científica y filantropíaen el contexto de la Gran Guerra? ¿Cuál era el estado cultural y político del feminismo en ese momento, y qué efectos tuvo en él la guerra? ¿Qué lugar podría ocupar la Primera Guerra Mundial en la historia social y política de las mujeres, y específicamente en la formación del feminismo en el país?

Tres tipos de documentación devienen imprescindibles para procurar una respuesta a estas preguntas. Los reportes consulares, resguardados en el Archivo Nacional, dieron seguimiento a la presencia y apuros de costarricenses en el continente europeo. Las revistas culturales, por su parte, abrieron sus páginas a la opinión de algunas mujeres eminentes que, poco a poco, se abrían campo en la

6 Frank Notten, La influencia de la Primera Guerra Mundial sobre las economías centroamericanas 19001929. Un enfoque desde el comercio exterior (San José: CIHAC-Escuela de Historia, 2012); Emmanuel Barrantes, “El ‘Patrón Oro’ y el 'Bimetalismo’ en Costa Rica (1896-1920): sus contradicciones”, en: Nueva historia monetaria de Costa Rica. De la Colonia a la década de 1930, (ed.) Ronny Viales (San José: EUCR, 2011), 221-301; Emmanuel Barrantes, Hilda María Bonilla y Olga Marta Ramírez, "Costo y condiciones de vida: la canasta de subsistencias en Costa Rica, 1914-1920”, en: Pobreza e historia en Costa Rica. Determinantes estructurales y representaciones sociales del siglo XVII a 1950, (ed.) Ronny Viales (San José: EUCR, 2009), 101-154.

7 Hugo Murillo, Tinoco y los Estados Unidos. Génesis y caida de un régimen (San José: EUNED, 1981); Jorge Rhenán Segura, La sociedad de las naciones y la política centroamericana 1919-1939 (San José: Euroamericana de Ediciones, 1993); Esteban Penrod, Las relaciones diplomáticas y consulares entre Costa Rica y Alemania (desde su inicio hasta el fin de la Segunda Guerra Mundial) (Trabajo final de graduación, Ministerio de Relaciones Exteriores y Culto, Instituto de Servicio Exterior Manuel María Peralta, Costa Rica, 1997). 
esfera intelectual del país; asimismo, reúnen una diversidad de imágenes sobre los acontecimientos y las vivencias de la guerra, incluyendo las de mujeres en distintas ocupaciones que tuvieron durante y dentro del conflicto. Finalmente, la prensa, en particular los diarios La Información y La Prensa Libre, siguieron en detalle la evolución de los acontecimientos de la guerra y sus múltiples efectos en el país, entre ellos la movilización de las mujeres.

A continuación se revisan algunos problemas de estudio trazados por la historiografía internacional de las mujeres en relación con la Primera Guerra Mundial. Después se reconstruye brevemente el cambiante escenario sociopolítico de las mujeres en el país, en el cual se desplegaron las diferentes repercusiones que tuvo la guerra. Por último se analizan los efectos de la Gran Guerra entre las mujeres costarricenses desde cuatro ejes: a) la imagen de la mujer y su participación en la guerra; b) las experiencias de las mujeres costarricenses en la Europa en guerra y en la Costa Rica afectada por ella; c) la movilización local desde la beneficencia y la caridad internacional; y d) la guerra en los orígenes del feminismo costarricense.

\section{Las mujeres y la Gran Guerra en la historiografía internacional}

En un importante balance general sobre la historiografía de la Gran Guerra, los especialistas Jay Winter y Antoine Prost disciernen una evolución analítica en tres corrientes: la primera, militar y política, la cual incluye los estudios de testigos contemporáneos; la segunda, social y muy cercana al paradigma marxista; la tercera, cultural, y es dentro de este pasaje de la historia social a la historia cultural en el último tercio del siglo XX que se ubica la historiografía de género y de las mujeres, al lado de otras dedicadas al estudio de las artes, de la memoria y el duelo, de la violencia del combate y de los horrores de la guerra, donde también se indaga sobre los modos en que mujeres y hombres se representaban tales mundos. ${ }^{8}$ Para Winter y Prost, la numerosa presencia de mujeres en las fábricas de guerra evoca dos interrogantes; si la guerra constituye un progreso o un paréntesis en la larga lucha por la emancipación de las mujeres, algo difícil de sostener por el regreso al viejo orden de género en la posguerra, y si tal presencia laboral incidió en el movimiento obrero, lo que parece tener más viabilidad por el importante protagonismo femenino en protestas, considerando que ellas no corrían el riesgo de ser enviadas al frente por ir a huelga. ${ }^{9}$ Este activo panorama entre el ingreso a las fábricas y la salida de ellas, no obstante, oculta el hecho de que la mayoría de las mujeres trabajadoras permanecieron en el campo; esto no evitó que en la época de posguerra circularan imágenes de

8 Jay Winter y Antoine Prost, The Great War in History. Debates and Controversies, 1914 to the Present (Cambridge, Inglaterra: Cambridge University Press, 2008), 6-33.

9 Ibid, 141-142. 
mujeres independientes y sin hijos en la ficción y en discursos políticos, como parte de los difundidos temores ante los trastornos de la guerra. No extraña, por ello, la "sobrefeminización" de las mujeres al ser reforzado el carácter reproductivo de la feminidad, en tiempos de desestabilización del orden familiar. ${ }^{10}$

La historiadora Françoise Thébaud abordó ampliamente el estudio de la historia de las mujeres en relación con la Primera Guerra Mundial; con respecto a esa oscilación conservadora en torno a la guerra y el género, Thébaud advierte que los gender studies invitan a no valorar las experiencias de emancipación y de su bloqueo desde las nociones del presente, sino más bien a atender la redefinición real y simbólica de los géneros, los roles sociales sexuados, los discursos, las representaciones y los vínculos entre la historia de género y la historia política. ${ }^{11}$ Con esta premisa, Thébaud se acerca a la vivencia de la movilización; antes del conflicto, los movimientos feministas sufragistas habían tendido a la radicalización y la cuestión femenina dominaba la esfera pública, pero la movilización masculina hizo que las mujeres fueran impulsadas a tomar los puestos de trabajo, así como en algunos casos recibieron subsidios de separación y por cantidad de hijos. Con la duración de la guerra se agrava la penuria económica, lo cual sobrecargó el trabajo doméstico, al mismo tiempo que la hostilidad se hacía sentir entre los sindicatos molestos por el ingreso laboral femenino y entre aquellos países que incluyeron mujeres en sus ejércitos como soldados o encargadas de diversos oficios: había una identidad masculina puesta en cuestión, lo cual alcanzó al campo literario y sus referencias al simbolismo de la castración. ${ }^{12}$

Las fotografías de los medios de la época retrataban a las mujeres en el espacio público; había científicas que contribuyeron con los avances en la medicina de guerra, pero también enfermeras que, vistas como fuente de consuelo del soldado, fueron muy alabadas así como deseadas sexualmente; de hecho, durante el conflicto aumentaron las tasas de ilegitimidad y de divorcio, lo cual quedó registrado en el erotismo de la literatura, de la prensa y de las tarjetas postales. La filantropía moderna e higienista fue otro activo campo de intervención entre las mujeres, así como surgió la figura de las asistentes o supervisoras de fábricas entre las clases media y alta; tales actividades tuvieron en cierto modo continuidad en la posguerra, cuando las altas tasas de mortalidad masculina y la caída de las tasas de natalidad consolidaron movimientos antes minoritarios como las natalistas, las familiaristas y las higienistas, hecho conducido no solo de arriba hacia abajo desde los estados, sino muy apropiado y liderado por las mujeres. ${ }^{13}$

10 Ibid, 165-168.

11 Françoise Thébaud, "La Primera Guerra Mundial: ¿la era de la mujer o el triunfo de la diferencia sexual?", en: Historia de las mujeres en Occidente. Tomo 5. El siglo XX, (eds.) Georges Duby y Michelle Perrot (Madrid: Taurus, 2005), 46-48.

12 Ibid, 49-61.

13 Ibid, 69-78. 
A pesar de los discursos feministas y de los estereotipos predominantes sobre los roles de género - mujer/paz, hombre/guerra- ${ }^{14}$ parece haber predominado el nacionalismo sobre el pacifismo; la guerra quiebra tanto el internacionalismo obrero como el feminista. Encuentros como el Congreso Internacional por la Paz Futura de 1915 en La Haya no tuvieron continuidad por las mismas circunstancias de la guerra; en Estados Unidos, la entrada en combate en 1917 diluyó el feminismo dentro de la unión patriótica. Thébaud no ve estas tendencias como traición o alienación, sino como la desembocadura en una lucha concreta: el sufragio femenino. No hay una relación uniforme entre la participación femenina en el esfuerzo de guerra, ya fuera en el frente doméstico o en el frente militar, con la posterior consecución de derechos ciudadanos; pero casos como el de Estados Unidos y Gran Bretaña sí tuvieron relación directa con la guerra. ${ }^{15}$ Junto al refuerzo del feminismo sufragista, las mujeres siguieron ocupando empleos en fábricas, en el sector de servicios o en profesiones liberales; además, hubo ciertos cambios en relación con la libertad de movimiento: la vestimenta no fue la misma, como tampoco lo fueron prácticas corporales como nuevos peinados, deportes y recreación. Antes que un fin del feminismo, concluye Thébaud, fue este un intervalo entre el de 1920 y el de 1960; atrás quedaba la igualdad y la especificidad sexual de 1910, dando paso a la diferencia y la complementariedad de los sexos, protegiendo a la madre y a la trabajadora, de allí el conservadurismo de la guerra. ${ }^{16}$

La perspectiva abarcadora de Thébaud puede complementarse con otras aproximaciones donde se analiza tanto el frente doméstico como el frente de combate y sus zonas inmediatas a la muerte. Los gobiernos de países participantes en la guerra apelaron constantemente al estoicismo de las mujeres en sus hogares; ellas mismas, de manera individual y colectiva, ofrecieron sus servicios. Cuando sus países fueron invadidos y las poblaciones desplazadas, ellas ayudaron a crear y sostener organizaciones voluntarias que trabajaron aliviando las necesidades de los refugiados, aunque también resintieron que estos fueran una competencia por los limitados recursos. Esto ocurría al mismo tiempo que se vivía bajo el riesgo de invasión de tropas extranjeras, lo cual suponía el peligro del abuso y la explotación sexuales; se debía velar por el sustento de sus familias, haciendo largas filas o asumiendo tareas de labranza que antes eran realizadas por animales ahora llevados al combate. Las organizaciones de mujeres no respondieron de modo uniforme a la guerra: algunas feministas defendieron el pacifismo hasta el fin, varias socialistas fueron duramente reprimidas, mientras que para otras las normativas de género se impusieron para hacer eco del heroísmo y la gloria de la batalla; entre algunas agrupaciones cristianas se crearon centros

14 Acerca del cambio en los estereotipos sobre las mujeres en la Primera Guerra Mundial, véase Graciela Padilla y Javier Rodríguez, "La I Guerra Mundial en la retaguardia: la mujer protagonista", Historia y Comunicación Social (España) 18 (2013): 191-206.

15 Thébaud, 89-95.

16 Ibid, 96-106. 
de entretenimiento para soldados en descanso o veteranos, atendidos por mujeres "respetables" que buscaban alejarlos del alcohol y de aquel sexo ilícito que provocaba campañas estatales para prevenir enfermedades venéreas. ${ }^{17}$

En el frente occidental de batalla algunas mujeres se trasvistieron como hombres para ser soldados, algo que reflejaba el idealismo militarista y el deseo de aventura, complementado por aquella literatura decimonónica que reivindicaba figuras como Juana de Arco y por los nuevos testimonios sobre las contribuciones de las mujeres a la guerra. La mujer soldado era en realidad una excepción; pero esa contradicción con la época no evitó que, como toda guerra, la de 1914-1918 fuera vivida como experiencia del cuerpo. La vivencia de ser enfermera cerca o dentro de los campos de batalla implicaba experimentar la tragedia corporal de la guerra; la crítica literaria Margaret R. Higonnet ha estudiado detallados testimonios sobre el presenciar traumas, mutilaciones, operaciones quirúrgicas y muertes. ${ }^{18}$

Para la historiadora Joanna Bourke, esta experiencia de la muerte es también un ecualizador del género, en el sentido de que la proximidad con la muerte imprime identidades de género de forma más intensa en participantes y observadores; el género, agrega Bourke, es performativo, es una hermenéutica aprendida que toma sus conocimientos de las interacciones entre los cuerpos, el lenguaje, la cultura y el ambiente. En este sentido, la vivencia extrema con la muerte reforzaba no solo la construcción de la heterosexualidad desde la intimidad epistolar, sino también desde la masculinidad valorizada por su agresividad y su orgullo viril en el combate, o desde el estoicismo de las enfermeras. Muchas mujeres fueron torturadas o asesinadas ${ }^{19}$ pero también estuvieron al otro lado de las armas y, como demuestra Bourke en su libro Sed de sangre, manifestaron placer al dejar su uniforme de enfermeras por el de soldados para alegrarse por la explosión de las bombas y por ser aceptadas entre compañeros de batalla. Era esta una forma de vivir la libertad, y por ello volver del frente fue para algunas una frustración. La autora, con esto, rompe con la idea de una mujer alejada de la línea de fuego y con los modelos de doncellas, vírgenes y madres patrióticas; ellas exigieron adiestramiento militar en medio de la retórica dominante del cuido y la crianza, por tanto algunos feminismos optaron por demandar reclutamiento antes que el voto, así que tanto participaron activamente en la fabricación de armas como se alistaron para matar, en casa o en las trincheras. ${ }^{20}$

17 Susan Grayzel, "Men and women at home", en: The Cambridge History of the First World War. Volume III: Civil Society, (ed.) Jay Winter (Cambridge: Cambridge University Press, 2014), 96-120.

18 Margaret Higonnet, “At the front", en: The Cambridge History of the First World War. Volume III: Civil Society, (ed.) Jay Winter (Cambridge: Cambridge University Press, 2014), 121-152.

19 Joanna Bourke, "Gender roles in killing zones", en: The Cambridge History of the First World War. Volume III: Civil Society, (ed.) Jay Winter (Cambridge: Cambridge University Press, 2014), 153-177.

20 Joanna Bourke, Sed de sangre. Historia íntima del combate cuerpo a cuerpo en las guerras del siglo XX (Barcelona: Crítica, 2008), 299-335. 
La modesta participación militar de los países latinoamericanos en la Primera Guerra Mundial hace difícil registrar tales experiencias para las mujeres; de hecho, las historias generales sobre las mujeres en América Latina cubren los años de la Gran Guerra sin hacer referencia a esta. ${ }^{21}$ Aunque falta más investigación para identificar casos específicos, ${ }^{22}$ las recientes aproximaciones generales a la historia del impacto de la guerra en la región incluyen un importante protagonismo femenino, ${ }^{23}$ si bien no desde el mundo de las trincheras, sí desde la beneficencia y la movilización por derechos. En su estudio sobre América Latina y la Gran Guerra, el historiador Stefan Rinke subraya entre las organizaciones y sociedades pro-aliadas argentinas y brasileñas la novedosa participación de las mujeres en las manifestaciones, así como voluntarias de la Cruz Roja. Las revistas culturales y la prensa, desde Argentina hasta Cuba y México, iban dirigidas también al público lector femenino cuando, desde los estereotipos de género, divulgaban asuntos de la "moda en la guerra", la imagen de la mujer como metáfora de la nación, de la vida o del ideal de humanidad en medio de la guerra, donde se destacaba el valor de la enfermera y la cuidadora. Al lado de la participación femenina en los movimientos pacifistas, algunos intelectuales reforzaron la idea de la madre sacrificada durante la guerra, y de la madre fecunda luego de esta, como forma de restablecer el orden tradicional de los géneros. Indudablemente, sostiene Rinke, la guerra fue un activador de distintas movilizaciones por derechos sociales, y de ello formaron parte las mujeres; para el movimiento feminista en Chile, la barbarie de la guerra perpetrada por hombres les daba un argumento para reclamar sus derechos; durante el conflicto crecieron notablemente las organizaciones de mujeres en países como Uruguay, Argentina y Chile, promoción a la que se sumaban los socialismos y anarquismos mexicano, peruano y chileno; luego de la guerra, la aprobación del derecho al voto en Alemania y Estados Unidos fortaleció igualmente las aspiraciones y redes trasnacionales sufragistas. ${ }^{24}$

21 Isabel Morant (dir.), Historia de las mujeres en España y América Latina. Volumen IV: Del siglo XX a los umbrales del XXI (Madrid, España: Cátedra, 2006).

22 Véase María Inés Tato, "En el nombre de la patria: asociacionismo y nacionalismo en la Argentina en torno a la primera guerra mundial", en: Actas XIV Encuentro de Latinoamericanistas Españoles, Congreso Internacional 1810-2010: 200 años de Iberoamérica (Santiago de Compostela, 15-18 de septiembre de 2010), 303-315.

23 Sin embargo, hay muy pocas referencias a las mujeres en Olivier Compagnon, América Latina y la Gran Guerra. El adiós a Europa (Argentina y Brasil, 1914-1939) (Buenos Aires: Crítica, 2014).

24 Stefan Rinke, Im Sog der Katastrophe. Lateinamerika und der Erste Weltkrieg (Frankfurt am Main: Campus Verlag, 2015), 125, 159, 241-243, 263, 279-281. 


\section{Mujeres, política y feminismo costarricense: una guerra sin huellas historiográficas}

Tal era el mundo alrededor de 1914. ¿Quedaron las mujeres costarricenses al margen de él? De momento, la historiografía sobre su participación sociopolítica y sus derechos entre fines del siglo XIX y comienzos del XX ha considerado una amplia gama de procesos dentro de los cuales, sin embargo, no se encuentra la coyuntura internacional de la Primera Guerra Mundial. La historiadora Eugenia Rodríguez identifica los años 1890-1910 como un primer período del movimiento sufragista, caracterizado por la apertura de la discusión periodística y las primeras formulaciones sobre la igualdad y los derechos políticos de las mujeres. ${ }^{25}$ Como apunta la politóloga Macarena Barahona, en 1890 tiene lugar el primer pronunciamiento a favor del sufragio femenino en el país, de parte del presidente José Joaquín Rodríguez (1890-1894) luego de que su candidatura fuera defendida públicamente por sectores católicos, frente al intento liberal de revertir su triunfo electoral en noviembre de 1889; en aquellos levantamientos populares, sugiere Barahona, pudo haber una participación femenina que incidiera en la posición del presidente, aunque no en la del Congreso, donde no se discutió el tema. ${ }^{26}$ Puede sumarse al contexto de este primer momento la incursión pública de las mujeres a partir de las reformas liberales en educación, con la creación del Colegio Superior de Señoritas (1888) y el consiguiente proceso de feminización docente, $\mathrm{y}$ la participación de las mujeres de clases media y alta en la beneficencia católica que no desapareció con las reformas liberales, las cuales redefinieron el papel de la madre como un deber cívico. ${ }^{27} \mathrm{La}$ abogada Ángela Acuña, principal figura del feminismo costarricense, formalmente constituido en 1923, ingresaría al Colegio Superior de Señoritas al comenzar el siglo $\mathrm{XX}$, realizando poco después sus estudios en Londres, Inglaterra, donde aparentemente asistió a los discursos y mítines de un feminismo sufragista tendiente cada vez más a la radicalización y la violencia; de allí regresará en $1910 .{ }^{28}$

El segundo momento del movimiento sufragista es definido por Rodríguez entre 1910-1923. ${ }^{29}$ Este es un período complejo en el cual se refuerzan las tendencias del anterior en cuanto a participación sociopolítica y docente femenina, culminando

25 Eugenia Rodríguez, "La lucha por el sufragio femenino en Costa Rica (1890-1949)", en: Un siglo de luchas femeninas en América Latina, (ed.) Eugenia Rodríguez (San José, Costa Rica: EUCR, 2005), 89-110. Los otros momentos son 1910-1923 y 1923-1949.

26 Macarena Barahona, Las sufragistas de Costa Rica (San José, Costa Rica: EUCR, 1994), 42-44.

27 Alfonso González, Vida cotidiana en la Costa Rica del siglo XIX. Un estudio psicogenético (San José, Costa Rica: EUCR, 1997); Luis Osvaldo Barrantes et al., Política social, beneficencia y abandono de niños en Costa Rica (1890-1930) (Tesis de Licenciatura en Historia, Universidad de Costa Rica, 1995); Steven Palmer y Gladis Rojas, "Educando a las señoritas: formación docente, movilidad social y nacimiento del feminismo en Costa Rica (1888-1925)", en: Educando a Costa Rica. Alfabetización popular, formación docente y género (1880-1950), (eds.) Iván Molina y Steven Palmer (San José, Costa Rica: Porvenir, 2000), 57-100.

28 Yadira Calvo, Ángela Acuña, forjadora de estrellas (San José, Costa Rica: ECR, 1989), 27-59.

29 Rodríguez, "La lucha por el sufragio femenino", 89-90. 
con la conformación de la Liga Feminista en 1923. En 1913, la reforma electoral por el voto directo, llevada al Congreso por el presidente Ricardo Jiménez (1910-1914), promovió al mismo tiempo el debate sobre la igualdad y los derechos políticos femeninos, lo cual no se eximió de fuertes sátiras misóginas en la prensa. ${ }^{30}$ Para entonces, se informaba constantemente de las actividades sufragistas en el mundo, y comenzaba la actividad intelectual sufragista de Ángela Acuña en la prensa, conferencias y revistas culturales, así como su participación en las filas del partido Unión Nacional con su candidato el Dr. Carlos Durán para las elecciones de 1914; ella, además, había logrado ingresar en 1912 al Liceo de Costa Rica, para varones, y en 1916 obtuvo el Bachillerato en Leyes en la Escuela de Derecho, por lo cual el mismo año presentó la solicitud al Congreso para modificar el artículo de la Ley Orgánica de los Tribunales que impedía a las mujeres ejercer el notariado. ${ }^{31}$

Si con Acuña empieza a tomar forma el feminismo de vertiente liberal en el país, con su énfasis en la igualdad de derechos y en la diferencia sexual a partir de los valores sociales asignados a la maternidad, también se hizo presente un feminismo dentro del movimiento obrero que pretendía educar a las mujeres para la reforma social y la dignificación de la vida de los trabajadores y sus hijos ${ }^{32}$ de este modo, las trabajadoras denunciaron la desigualdad salarial con respecto a los hombres desde 1910, participaron en la organización del Primer Congreso Obrero Centroamericano de 1911 y en la celebración del primer $1^{\circ}$ de mayo en $1913 .{ }^{33}$ La historiadora Patricia Alvarenga ha revelado, no obstante, cuán profundas podían ser las diferencias de ese feminismo obrero con respecto al liberal sufragista, sobre todo cuando se pronunciaba por el amor libre y el disfrute femenino de los placeres de la vida moderna, y cuando criticaban, junto con otros intelectuales hombres, instituciones como el matrimonio y la Iglesia, lo cual no excluía la presencia de versiones tradicionales de género y paternalismos masculinos dentro de esa versión obrera del feminismo, justo en el momento en que se debatía sobre el impacto de la industria de la moda en los cuerpos y las conductas de las mujeres, ${ }^{34} \mathrm{y}$ cuando estas aparecían en las portadas de revistas ilustradas como prototipos de belleza y moralidad. ${ }^{35}$

Las labores filantrópicas de las mujeres no se limitaron al quehacer de la Iglesia católica, sino también a la incipiente política social liberal que canalizó los

30 Barahona, 53-69; Rodríguez, "La lucha por el sufragio femenino", 90.

31 Calvo, 70-89.

32 Rodríguez, "La lucha por el sufragio femenino", 92-95.

33 Esa participación no ha podido ser documentada más allá de algunas referencias indirectas como una ofrenda floral para una trabajadora en un cementerio, o algunas alusiones en los discursos de los escritores y educadores Carmen Lyra y Joaquín García Monge. Véase Virginia Mora, Mujer e historia: la obrera urbana en Costa Rica (1892-1930) (Tesis de Licenciatura en Historia, Universidad de Costa Rica, 1992), 162-192.

34 Patricia Alvarenga, Identidades en disputa. Las reinvenciones del género y de la sexualidad en la Costa Rica de la primera mitad del siglo XX (San José, Costa Rica: EUCR, 2012), 55-73, 145-170.

35 Virginia Mora, Rompiendo mitos y forjando historia. Mujeres urbanas y relaciones de género en Costa Rica a inicios del siglo XX (Alajuela, Costa Rica: MHCJS, 2003), 162-163. 
discursos de la maternidad para darles un contenido científico institucionalizado en la formación de las escuelas de Obstetricia (1900) y Enfermería (1917), en programas de atención social como La Gota de Leche (1913), y en la oficialización del Día de la Madre (1932). ${ }^{36}$ Las educadoras tuvieron un papel fundamental en esta atención de lo social; la exitosa reforma educativa de fines de siglo y el consiguiente proceso de feminización docente fueron determinantes para el buen término de las campañas contra la anquilostomiasis desarrolladas en cooperación con la Fundación Rockefeller desde 1914, en las cuales las maestras fungieron como visitadoras sociales y pedagogas de la cultura higienista y de la difusión de la bacteriología. ${ }^{37}$ Fueron también educadoras las que, junto con las estudiantes del Colegio Superior de Señoritas, se movilizaron para provocar la caída de la dictadura de los Tinoco (1917-1919) en agosto de 1919, un proceso de singular importancia para el reconocimiento de la causa política del voto femenino, primero, porque esta tuvo un uso electoral en el antitinoquista y luego presidente Julio Acosta (1920-1924); segundo, consolidó entre las estudiantes del Colegio un proyecto legislativo en junio de 1923 para la aprobación del sufragio, finalmente no aprobado en el Congreso; y tercero, porque contribuyó a conformar en octubre de 1923 la Liga Feminista, en cuya junta directiva estuvieron Ángela Acuña y Ana Rosa Chacón - una graduada del Colegio y la otra maestra de educación física allí, ambas protectoras en La Gota de Leche- ${ }^{38}$ así como Esther de Mezerville, luego directora del Colegio. ${ }^{39}$

Este evento pareciera haber transformado profundamente la cultura política de las mujeres y su capacidad organizativa, pero ello no se limitó a la importante presencia que tuvo en adelante la agrupación feminista, sino que fue visible también en la participación de las mujeres en las huelgas obreras de 1920 por mejores salarios y jornadas, y en la ley de inquilinato en 1922; en la propagación de centros recreativos, deportivos y sociales de mujeres; ${ }^{40}$ y en su incursión en los primeros partidos políticos de contenido ideológico y obrerista en el país como el Partido Reformista (1923) y el Partido Comunista (1931) ${ }^{41}$ A pesar de lo anterior, no hay una huella historiográfica sobre la posibilidad, por remota que

36 Eugenia Rodríguez, "Inventando el día de la madre en Costa Rica: 1890-1932", Reflexiones (Costa Rica) 75 (octubre, 1998): 33-42; Ana Paulina Malavassi, "De parteras a obstétricas: la profesionalización de una práctica tradicional. Costa Rica 1900-1940. Examen preliminar", en: Quinto Congreso Centroamericano de Historia (San Salvador, 2000); Ana María Botey Sobrado, "De la beneficencia a la filantropía "científica': la fundación de La Gota de Leche (1913)", Diálogos. Revista Electrónica de Historia (Costa Rica) número especial (2008), URL: https://revistas.ucr.ac.cr/index.php/dialogos/article/view/31243.

37 Steven Palmer, "Salud imperial y educación popular. La Fundación Rockefeller en Costa Rica desde una perspectiva centroamericana (1914-1921)", en: Educando a Costa Rica. Alfabetización popular, formación docente y género (1880-1950), (eds.) Iván Molina y Steven Palmer (San José: Porvenir, 2000), 129-157.

38 Mora, Rompiendo mitos, 196.

39 Barahona, 60-79; Palmer y Rojas, 87-92.

40 Mora, "Mujer e historia: la obrera urbana en Costa Rica", 162-192.

41 Mora, Rompiendo mitos, 211-230, 245-261; Eugenia Rodríguez, "Madres, reformas sociales y sufragismo: el Partido Comunista de Costa Rica y sus discursos de movilización política de las mujeres (1931-1948)", Cuadernos Intercambio sobre Centroamérica y el Caribe (Costa Rica) 11, n. 1 (enero-junio, 2014): 45-77. 
sea, de que la Primera Guerra Mundial tuviera algo que ver con estas transformaciones. ¿Fue así realmente? ¿Quedaron las mujeres costarricenses al margen de un mundo en guerra que estremeció el orden de los géneros?

\section{La Gran Guerra de las mujeres}

Los procesos arriba descritos tienen una relevancia considerable en el momento de poner en perspectiva los efectos que tuvo la guerra en el mundo social, cultural y político de las mujeres costarricenses. Tal impacto se verá en este apartado a partir de las fuentes ya mencionadas -correspondencia diplomática, prensa y revistas culturales- y desde cuatro vertientes: primero, la imagen de la mujer en la guerra y su participación en ella; segundo, las experiencias de mujeres costarricenses que radicaban en Europa en el momento de la guerra, o que vivieron esta desde sus efectos en Costa Rica; tercero, la movilización local a partir de la incursión en actividades de beneficencia y caridad internacional; y finalmente, los modos en que la guerra se inscribe en los orígenes del feminismo costarricense.

\section{La imagen de la mujer y su participación en la guerra}

Como bien lo ha demostrado la historiografía internacional, las mujeres de aquel mundo en guerra no se limitaron a agitar pañuelos para despedir a sus amados convertidos en soldados, y la sociedad costarricense tuvo distintos canales informativos para enterarse de esto. La cultura visual generada por la guerra abrió un espectro gráfico y textual que mostraba la diversidad de experiencias femeninas sobre la guerra; puede verse en la siguiente composición fotográfica, la cual reúne distintas imágenes obtenidas de las revistas culturales y de la prensa entre 19141915, que las mujeres no constituían un conjunto social homogéneo que uniformara sus experiencias; unas pertenecían a la realeza (1-2), como lo eran la princesa imperial Victoria Luisa, hija del emperador alemán Guillermo II, quien aparece caminando acompañada de su esposo y de un militar, o la hija del zar ruso, la gran duquesa Tatiana, quien posa para un retrato. La apacible vida que las imágenes revelan sobre ellas contrasta con las escenas de una cotidianidad más cercana al combate, como se ve con la dama berlinesa que reparte cigarrillos a reservistas camino a la guerra (3), o con las mujeres que, entre las trincheras, llevan nueces a los soldados belgas (5), mientras algunas escolares campesinas en Alemania ensayan señales del ejército (4), una niña parisina relata la historia del bombardeo alemán por el cual perdió una pierna y le fue sustituida por una prótesis (6), y una mujer toca música con sus hijos que bailan para pedir limosna (7). 


\section{Imagen 1 \\ Diversidad de experiencias de mujeres en la Primera Guerra Mundial en revistas y periódicos costarricenses}

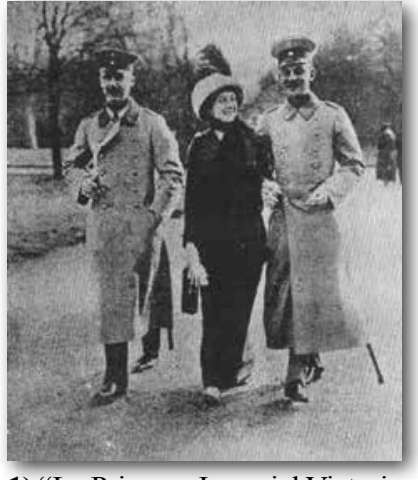

1) "La Princesa Imperial Victoria Luisa", Pandemonium, $\mathrm{N}^{\circ} 119$, 30 de setiembre de 1914, 701 .

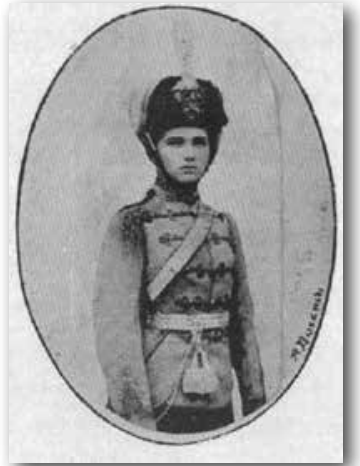

2) "La Gran duquesa Tatiana. Hija del Zar de Rusia", Pandemonium, $\mathrm{N}^{\circ} 128,15$ de febrero de 1915.

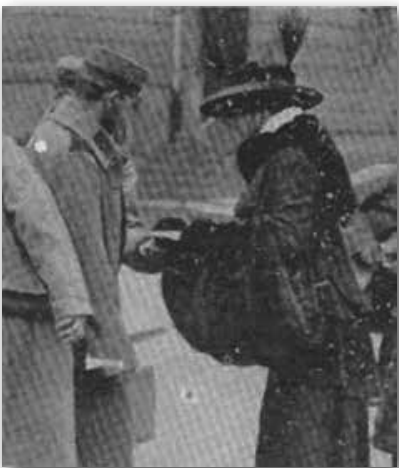

3) "Dama berlinesa distribuyendo cigarros a los reservistas que marchan a la guerra", Pandemonium, $\mathrm{N}^{\circ} 127,30$ de enero de 1915.

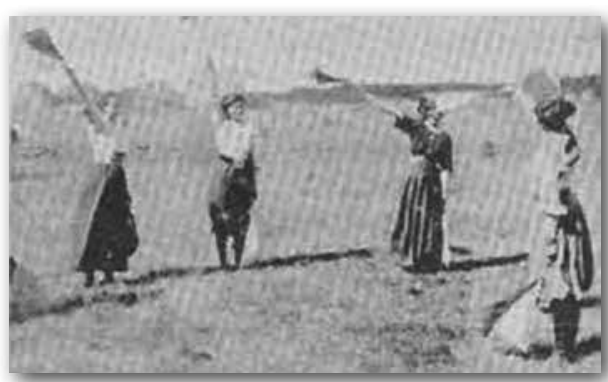

4) "Muchachas escolares campesinas de Alemania ensayando señales del ejército", Pandemonium, $\mathrm{N}^{\circ} 120,15$ de octubre de 1914, 720.

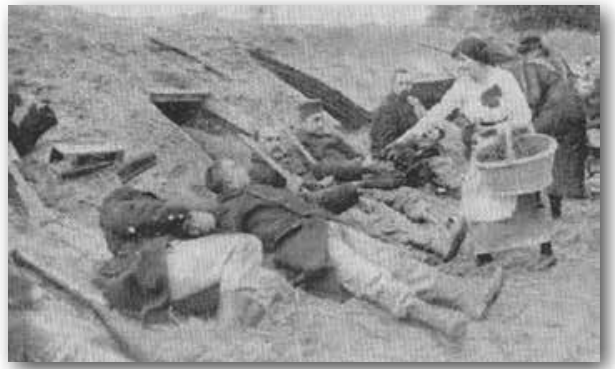

5) "Mujeres belgas repartiendo nueces momentos antes de un bombardeo", Pandemonium, $\mathrm{N}^{\circ} 122,15$ de noviembre de 1914, 777.

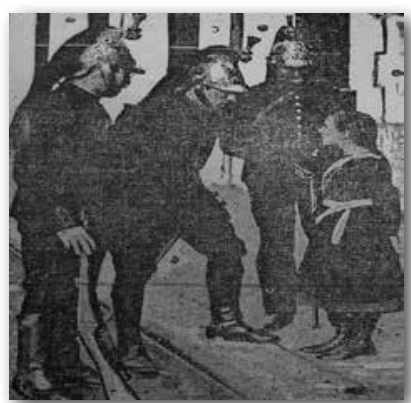

6) "Una criatura de París, víctima de una bomba aérea de los alemanes, cuenta su historia a algunos soldados...", La Información, 11 de febrero de 1915, 1 . 


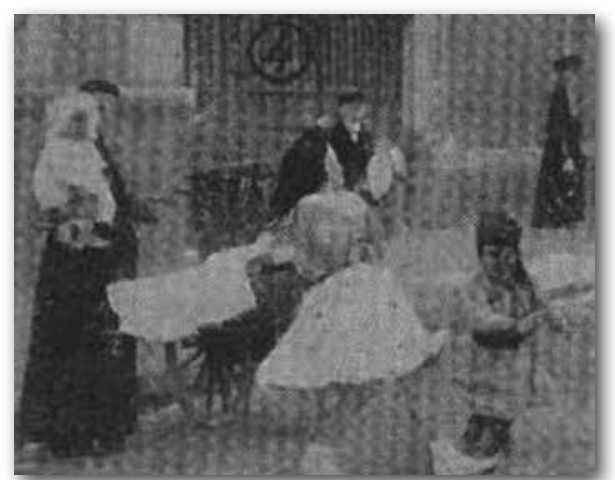

7) "La explotación de los niños", Pandemonium, $\mathrm{N}^{\circ} 129,28$ de febrero de 1915.

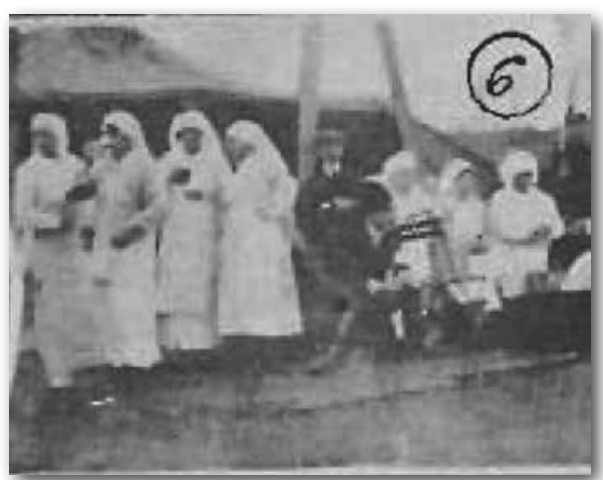

8) "Damas de la Cruz Roja francesa que atienden heridos en un puesto de Aubervillers", Pandemonium, $\mathrm{N}^{\circ} 124,15$ de diciembre de 1914, 848.

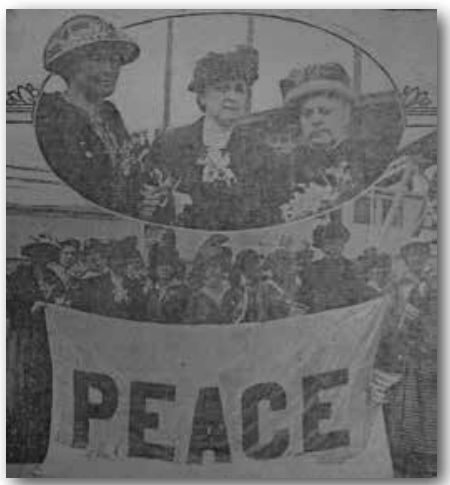

9) "Isar's Troops drive German T[ilegible]", La Información, 8 de mayo de 1915,8 .

Si bien la prensa costarricense, como en el resto de Centroamérica, padeció los excesos de propaganda antigermana durante el conflicto, ${ }^{42}$ las revistas culturales tendieron a equilibrar más la información, al menos en los primeros años de la guerra. Las imágenes anteriores, en tal sentido, no deben dejar de comprenderse dentro del espectro visual con que el país podía representarse lo ocurrido en Europa; esto es determinante en un momento histórico en el cual, como se indicó antes, las revistas incluían a mujeres en sus portadas y construían con esto no solo imaginarios de belleza, sino también otros espacios públicos de reconocimiento social para las mujeres. El espectro visual es, claro, mucho más amplio; las exhibiciones cinematográficas, por ejemplo, igualmente ofrecieron imágenes de las mujeres en la guerra, como aquella titulada Civilización (1917),

42 Vega, "Guerra, prensa y manipulación informativa”, 153-179. 
donde "el rey, conmovido, horrorizado por su propia obra, vuelve al palacio y accede a la petición de millares de mujeres que piden la paz".43

La diversidad de experiencias de las mujeres durante la guerra, como queda reflejada en ese marco visual, fue, asimismo, motivo de información en la prensa y de extendidas reflexiones en las revistas. Madame Thébes, una profetisa parisina, ejercía su oficio de predicciones sobre el futuro augurando que luego del conflicto Francia "se pondrá al frente de una crusada [sic] contra la despoblación" y las "mujeres serán menos frívolas y cuidarán más de sus hogares". ${ }^{44}$ En contraste, para Roberto Molina, cuya crónica fue premiada en el concurso literario español del Círculo de Bellas Artes, el problema de fecundación durante la guerra era compensado con las oportunidades que permitirían a las mujeres ampliar sus derechos y ser heroínas europeas:

\footnotetext{
"el obscuro cronista piensa en los millones de mujeres condenadas a una castidad forzosa, después de la horrible siega de varones, y señala a esta virtud un lugar preeminente entre las muchas que han de adquirir extraordinario florecimiento cuando se extingan las postreras luminarias del formidable incendio de la gran Sodoma. Y la mujer, que hace años viene luchando por la conquista de más amplios derechos que le permitan intervenir en la 'cosa pública', vendrá a ser ahora, por el imperativo mandato de la necesidad, requerida para contribuir con su personal esfuerzo al resurgimiento de la Europa agonizante, invadiendo los talleres de la industria, los puestos vacantes de las factorías, los altos sitiales de la Ciencia y el Arte, y los sillones de la sedentaria y necesaria burocracia". ${ }^{45}$
}

Una posición similar tenía el escritor francés León Abensour, uno de esos "fervientes defensores de la causa de las mujeres", quien publicara, en medio de la guerra, un libro donde apreciaba a las "valientes, mártires, heroínas y suplentes", gracias a las cuales, durante el conflicto, "ningún comercio se suspendió en los campos de Francia. No faltó quien amasara el pan, ni aprendices [...] que degollaran las reses, ni la fábrica de electricidad dejó de facilitar luz", la mujer "del boticario siguió también sirviendo a sus parroquianos" y, en "ausencia total de médicos, se vio [...] a mujeres experimentadas ayudar a las parturientas", por lo cual ella "ha ganado su propia victoria" y la "paz también será para ella un desquite y una liberación". ${ }^{46}$

Nada parece haber despertado más el imaginario heroico sobre las mujeres que el papel cumplido por las enfermeras. De esta actividad también aparecieron imágenes como la incluida en el cuadro (8), e incluso hubo reportes diplomáticos costarricenses que, desde la legación de París, aseguraban haber visto la

43 La Información, "El estreno de esta noche... Civilización", 4 de febrero de 1917, 3.

44 La Información, "La célebre profetisa Madame Thébes asegura que la guerra europea terminará a principios del año de 1915", 20 de diciembre de 1914, 1.

45 Roberto Molina, "Madres de la Patria", Colección EOS, 28 (15 de febrero de 1915): 148-151.

46 La Información, "El libro de oro de las mujeres de la guerra. Las heroínas francesas pintadas por el escritor León Abensour", 28 de octubre de 1917, 2. 
generosidad y buen trato de las enfermeras francesas con los heridos alemanes. ${ }^{47} \mathrm{El}$ artista y soldado argelino-francés Paul Margueritte afirmaba que el servicio médico francés durante la guerra se encontraba excelentemente organizado gracias a dos asociaciones: "Las Damas de la Cruz Roja y las Damas de Francia que forman un personal muy numeroso de enfermeras diplomadas con todas las garantías". ${ }^{48} \mathrm{De}$ una aristocrática dama inglesa, decía el escritor español Ángel Guerra:

\begin{abstract}
"La prensa francesa ha rendido un homenaje de admiración y de gratitud a una heroína de singulares méritos, cuya figura se ha destacado en el curso de esta guerra con poderoso relieve./ No se trata de una heroína a la antigua usanza, de las que combatían con las armas en las manos sobre los campos de batalla, como Juana de Arco, ni de las que alentaban con su presencia sobre las murallas de una ciudad asediada el espíritu de las tropas, como nuestra Agustina de Aragón./ El papel de estas nuevas heroínas es más silencioso, pero no menos admirable./ La figura sobresaliente ahora entre otras muchas, ha sido Lady Rodney./ Ella ha abandonado las comodidades y el reposo de su residencia en Londres para organizar ambulancias y hospitales de heridos en Francia". ${ }^{49}$
\end{abstract}

A pesar de la poca participación de las mujeres en el frente, la información recibida en el país las mostraba como testigos o víctimas de los horrores de la guerra, ocurridos principalmente en el frente doméstico. Sobre este tema se mencionan las violaciones a mujeres y niñas, ${ }^{50}$ su fusilamiento y mutilación, ${ }^{51}$ el asesinato de ancianas enfermas, ${ }^{52} \mathrm{o}$ filmes como El patriota y el espía en el que aparecen las madres que pierden a sus hijos, las viudas a sus esposos, y las novias a sus prometidos..$^{53} \mathrm{En}$ el horror de la guerra es representado con frecuencia el cuerpo herido y mutilado, pero el de la mujer despertaba mayor indignación entre algunos observadores:
"Dos soldados alemanes llamaron a la verja -del Hospital de Santo Tomás-. En una camilla traían una mujer de unos veinticinco años y a su niñita de tres. Uno de los soldados lloraba; el otro parecía hallarse conmovido y avergonzado. 'Esto es horroroso nos dijo el primero; ya esto no es guerra'. La mujer tenía un balazo en el costado y encima de la rodilla una herida horrible: el proyectil había destrozado los músculos y fracturado el hueso de un modo espantoso. La niña estaba herida en la rodilla. La mujer, llamada Emilia Janssens, había sido expulsada de Aershot junto con algunos centenares de conciudadanos; los soldados alemanes le habían dicho que iban a ser embarcados en Lovaina en un tren y desterrados a Alemania como

47 Archivo Nacional de Costa Rica -en adelante, ANCR-, Cajas de Relaciones Exteriores, Francia, 22279, 23 de febrero de 1915.

48 Paul Margueritte, "Las guerras modernas y las hecatombes. Los servicios sanitarios y los heridos", $L a$ Información, 25 de marzo de 1915, 5.

49 Ángel Guerra, "La mujer y la guerra", Pandemonium, 28 de febrero de 1915, 129.

50 La Información, "Texto completo del primer informe oficial de la Comisión de investigación nombrada para comprobar las atrocidades alemanas", 25 de febrero de 1915, 7.

51 La Información, "Conversando con el General Romain, sobre la guerra europea y sus consecuencias", 14 de marzo de 1915,5 .

52 Enrique Gómez, "Los alemanes y el clero", La Información, 10 de abril de 1915, 7.

53 La Información, "Horrores de la guerra", 28 de mayo de 1916, 5. 
prisioneros de guerra. Mientras aguardaban el rebaño humano en la calle de la Estación, bruscamente, sin motivo, los soldados alemanes se pusieron a tirar sobre el grupo [...] Los médicos de Santo Tomás decidieron amputarle inmediatamente la pierna a la pobre mujer". ${ }^{54}$

Tal indignación fue reproducida por los testimonios de hombres costarricenses que residían en Europa durante el conflicto; era común que la correspondencia privada venida del continente europeo fuera publicada por familiares en la prensa costarricense. De la carta de Rodrigo Peralta a su madre se lee: "De la guerra le diré que es lo más triste, lo más doloroso ver a las pobres madres con sus hijos llorando porque sus maridos han sido llevados al ejército y ellas no tienen que comer". ${ }^{55}$ En ocasiones, esa correspondencia era reflejo del resentimiento local que provocaba la guerra hacia las comunidades extranjeras de países participantes, como la carta dirigida por Eliécer Sibaja Lobo al miembro de la comunidad alemana Juan Kumpel, donde se reprochaba la vulneración de la neutralidad belga por el ejército germano: "sus mujeres violadas, sus ancianos y niños atropellados y ultrajados por la soldadezca [sic] y aún por la oficialidad del ejército prusiano, honra y pres [sic] de la Germania [... que mata] despiadadamente mujeres y niños". ${ }^{56} \mathrm{Si}$ no los sufrían directamente, las mujeres presenciaron aquellos hechos con horror y desesperación: unos "jóvenes ticos" de paso por Bélgica relataban que "Los parientes de la joven difunta nos contaron que los alemanes, habiendo tomado por espía al esposo de aquella joven, lo mataron en su presencia; y que ella, impresionada por la escena, se había vuelto loca y suicidado". ${ }^{57}$ No todas las experiencias retratadas por los testigos directos costarricenses fueron tan dramáticas; algunos hablaron de las filas de hombres y mujeres para entrar a un banco ${ }^{58} \mathrm{o}$ contaban con admiración que algunas "mujeres cargaban rifles que llevaban a los cuarteles; había entre aquellas patriotas quienes soportaban el peso de tres armas", ${ }^{59}$ mientras otros relataron el patriotismo despertado en ellas por la guerra: "Las mujeres cosen y tejen en servicio de la Cruz Roja, y nadie quiere permanecer inactivo [...] Cuando [los soldados] pasan por las calles, en formación, les obsequian cervezas, tabacos, frutas; en fin, las mujeres ofrecen desalojar sus casas para que las ocupen los soldados!", ${ }^{60}$ referencia que ilustra bien la imagen 3 del cuadro anterior.

54 La Información, "Las atrocidades alemanas. Segundo aniversario del suplicio de Lovaina", 25 de mayo de $1916,5$.

55 La Prensa Libre, "Un costarricense que presencia el fusilamiento de dos alemanes en Lovaina. Carta de Bélgica escrita por el joven costarricense don Rodrigo Peralta a su señora madre", 8 de setiembre de 1914, 2.

56 Eliécer Sibaja, "Carta", La Prensa Libre, 31 de marzo de 1916, 3.

57 La Información, "Aventuras de jóvenes ticos en la guerra europea", 7 de octubre de 1914, 7.

58 Santiago Durán, "Impresiones de la guerra", La Prensa Libre, 13 de octubre de 1914, 3.

59 La Prensa Libre, "Impresiones recogidas en Bélgica durante los primeros días de la guerra por el joven costarricense don Jorge Mullner", 20 de octubre de 1914, 3.

60 La Prensa Libre, "Carta de don Juan Loots para su señora, escrita en Amberes antes de la caída de la ciudad", 14 de octubre de 1914, 2. 
En medio de este conjunto de representaciones sobre las experiencias de las mujeres en la guerra, algunos intelectuales costarricenses reflexionaron sobre los posibles cambios sociales y de género que se anunciaban. El apoyo intelectual masculino a la causa de las mujeres no era nuevo; figuras como José Fabio Garnier y Joaquín García Monge externaron desde temprano un estímulo paternal hacia tales cambios; ${ }^{61}$ y el educador Omar Dengo, con un reciente pasado anarquista como el de estos últimos, también lo hizo, pero poniendo atención al escenario de la guerra. Educador y luego Director de la Escuela Normal de Heredia (1914), Dengo tuvo en la guerra una especie de pasaje entre su radicalismo político y la teosofia ${ }^{62}$ además, escribió sobre aquella con tono lastimoso y apelando al sentimiento filial: "La hermana enferma, el cortijo solitario, la patria dolorida, el cuerpo fatigado, la gloria al frente y el anhelo de ella en el corazón [...] el mundo arde de guerra, hermanas [...] Pero sobre todo, hermanas, los niños lloran, como pichoncitos caídos". ${ }^{63}$ En el anuncio de una nueva civilización imbuida de espiritualismo, Dengo vio en la experiencia de las mujeres en la guerra una confirmación de los cambios:

\begin{abstract}
"Los profetas de la presente edad anuncian que este será el siglo de la mujer. Lo que no requiere más confirmación, ni la encuentra más elocuente, que la actitud de la mujer en medio de las tempestades de la Gran Guerra. La mujer ha puesto en evidencia posibilidades que entrañan para el mundo la promesa de un nuevo continente del espíritu. Quizá ninguna fuerza influirá más poderosamente en la obra de reconstrucción ahora iniciada, que el corazón femenino. De ahí que la Comasonería, como el voto de la mujer, se difundan con admirable prodigalidad". ${ }^{64}$
\end{abstract}

No hay en Dengo una alusión directa a las mujeres en Costa Rica, de modo que sus reflexiones se inscriben dentro del conjunto de representaciones que, desde el país y a partir de diferentes canales de información, se construyeron sobre la experiencia femenina en la guerra. Era esta una mirada lejana a esa experiencia, confirmada en algunos trazos por el testimonio masculino directo que retrataba la vivencia de otras mujeres en otros lugares. Pero, ¿tan alejada estaba la guerra de la realidad de las mujeres costarricenses?

\title{
La guerra vivida entre dos continentes
}

Las mujeres costarricenses se vieron implicadas de distintas formas en la Gran Guerra; por supuesto, el lugar en donde se encontraran determinaba en

\footnotetext{
61 Alvarenga, 62-73.

62 Magdalena Alfaro y Marie Claire Vargas, "Semblanza y liderazgo de Omar Dengo: vigencia de su pensamiento", Revista Electrónica Educare (Costa Rica) 13, n. 1 (junio, 2009): 153-165, URL: http://www. revistas.una.ac.cr/index.php/EDUCARE/article/view/1484.

63 Omar Dengo, "La oración de las palomas", en: Omar Dengo: Escritos y discursos, (ed.) María Eugenia Dengo (Heredia: EUNA, 2007), 115-116. Publicado originalmente en La Información, 7 de febrero de 1915.

64 Omar Dengo, "La Comasonería”, en: Dengo, 210-212. Publicado en 1919.
} 
buena medida sus vivencias, por lo tanto es importante, en principio, discernir el lugar de su experiencia, ya fuera si se encontraban en Europa o si vivían la conflagración desde sus efectos en el país.

En el caso de las mujeres costarricenses que por distintos motivos se encontraban en Europa en el momento de estallar la guerra, las experiencias estaban vinculadas a la interrupción de los estudios, de sus diversas actividades, del transporte marítimo y de los flujos de dinero que hacían posible su residencia al otro lado del Atlántico. Las legaciones y los consulados en Europa tuvieron una agitada e inusual labor para poder ayudar a resolver, caso por caso, las circunstancias agobiantes que pasaban los y las costarricenses; los reportes enviados informaron constantemente de la situación de las ciudades en guerra, de las rutas de circulación y de los mecanismos de financiamiento posibles para repatriar a los nacionales.

Muy poco después de iniciado el conflicto, el ingeniero Nicolás Chavarría envió cables a Bélgica para que sus hijos Nicolás y las señoritas Marina y Amalita tomaran un vapor de vuelta a Costa Rica; el Ministro de Obras Públicas belga le contestó que las comunicaciones estaban interrumpidas y que no era posible que sus hijos hicieran el viaje de forma segura; también recibió correspondencia de sus hijas, contando que su Colegio Nuestra Señora de Sión, en Amberes, "había sido desalojado, pues se le destinaba para Hospital de sangre a donde se enviarían seiscientos heridos". ${ }^{65}$ En Lovaina, los estudiantes del Colegio de las Tres Sainte Trinité habían sido trasladados a Melle por protección, y los hijos del doctor Ángel Velázquez habían sido llevados por su madre a Blankenbourgh; indicaba el encargado de la Legación de Costa Rica en Londres que "varios de esos jóvenes quieren regresar a Costa Rica por instrucciones de sus familias o por propia voluntad", pero era difícil conseguir pasajes en los vapores ya abarrotados, y la mayoría "se encuentran sin recursos, porque las casas que suplean [ $\mathrm{sic}]$ estos se han negado a hacerlo y sus familias encuentran dificultad para enviarles fondos". ${ }^{66}$

No solo había dificultades financieras que impedían retornar al país; en algunos casos eran motivos de salud los que mediaban. La orden gubernamental de regreso inmediato recibida por Carlos M. Jiménez tenía la circunstancia especial de que "salvo las incomodidades inherentes a quien viaja con numerosa familia y en momentos en que los transportes no abundan", no le era posible retornar "hallándose su esposa en estado interesante y en vísperas de alumbramiento", lo cual traía complicaciones pecuniarias al gobierno, algo apenas compensado por las casas comerciales que contribuían a su estadía. ${ }^{67}$ Una familia

65 La Prensa Libre, "Las señoritas Chavaría Flores no pueden salir de Bélgica", 25 de agosto de 1914, 1.

66 ANCR, Cajas de Relaciones Exteriores, Inglaterra, 22.191, 3 de setiembre de 1914. Legación de Costa Rica en Londres a Ministro de RREE.

67 ANCR, Cajas de Relaciones Exteriores, Francia, 22.156, 11 de noviembre de 1914. Legación de París a Ministro de RREE; ANCR, Cajas de Relaciones Exteriores, Francia, 22158, 17 de noviembre de 1914. Carlos M. Jiménez a Ministro de RREE. 
de apellido Rivera también alegó que su hija recibía un tratamiento médico en Europa que impedía retornar de inmediato al país. ${ }^{68}$

Ante las premuras económicas que impedían a familias o familiares retornar al país para huir de la guerra, el gobierno, a través de sus legaciones en Europa, o por medio de casas comerciales, medió para financiar aquel deseado u obligado regreso, conviniendo que lo aportado fuera retribuido una vez instaladas las personas en el país. Por este mecanismo, Manuel María Peralta, representante en la Legación costarricense en París, dio orden al cónsul en Berna de entregar a la señora Villafranca mil francos, siendo entregados más bien quinientos por mediación del cónsul de Ginebra; ${ }^{69}$ al vivir en un país neutral como Suiza, sin embargo, la Legación en Londres se negó luego a entregarle dinero, aduciendo la posibilidad que tenía el esposo, Rafael Villafranca, de enviar sus remesas desde Costa Rica. ${ }^{70}$ Otro caso se encuentra con el aporte de la Legación de Londres a Carmen Montero, y a una familia de apellido Romero, mientras otras como la familia Sáenz pudieron hacerlo por su cuenta. ${ }^{71}$ Con éxito, y gracias a las contribuciones de las distintas legaciones y de las casas comerciales, pudieron retornar las señoritas Emilia Vargas Quesada, doña Delfina Guardia y Quirós, doña Dolores Castro, así como la señora de Benedictis y su hijo:72 la ruta tomada por algunas personas consistía en embarcarse en el vapor Lusitania, rumbo a Nueva York, de donde tomaban un vapor de la United Fruit Company que llegaba al puerto de Limón. ${ }^{73}$

Estas mujeres, ya fueran esposas o hijas, aparecieron en la documentación como objeto de contribuciones económicas para regresar al país; pero había otras que, en medio de la guerra, tenían la capacidad económica para permanecer en Europa o para ayudar desde allí o desde Costa Rica a otros bajo apremio. Un estudiante en Italia, Humberto Bertolini Molina, pedía al consulado en Bolonia ser repatriado por no poder recibir el dinero que era enviado desde San José por su madre, la viuda Estela Molina; ${ }^{74}$ el auxilio de cien francos que Arturo Maure pidió a la Legación de

68 ANCR, Cajas de Relaciones Exteriores, Inglaterra, 22.191, 25 de setiembre de 1914. Cónsul en Londres a Ministro de RREE.

69 ANCR, Cajas de Relaciones Exteriores, Francia, 22.156, 15 de setiembre de 1914. Legación de Costa Rica en París a Ministro de RREE Manuel Castro Quesada.

70 ANCR, Cajas de Relaciones Exteriores, Inglaterra, 22.191, 12 de octubre de 1914. Legación de Londres a Ministro de Relaciones Exteriores.

71 ANCR, Cajas de Relaciones Exteriores, Inglaterra, 22.191, 25 de setiembre de 1914. Cónsul en Londres a Ministro de RREE.

72 ANCR, Cajas de Relaciones Exteriores, Inglaterra, 22.191, 12 de octubre de 1914. Legación de Londres a Ministro de Relaciones Exteriores; ANCR, Cajas de Relaciones Exteriores, Francia, 22.279, 28 de enero de 1915. Legación de París a Ministro de RREE; ANCR, Cajas de Relaciones Exteriores, Inglaterra, 22.191, 30 de octubre de 1914. Legación de Londres a Ministro de RREE. La prensa consignó el regreso también exitoso del cónsul italiano Félix Scaglietti con su esposa, pero no se indicó si lo hicieron con recursos propios o con alguna contribución. La Prensa Libre, "Regresó el cónsul italiano", 8 de julio de 1915, 3.

73 ANCR, Cajas de Relaciones Exteriores, Inglaterra, 22.191, 19 de octubre de 1914. Legación de Londres a Ministro de RREE.

74 ANCR, Cajas de Relaciones Exteriores, Italia, 22.318, 12 de abril de 1914. Cónsul de Bolonia a Ministro de RREE Manuel Castro Quesada. 
París para continuar sus estudios fue entregado gracias a la seguridad de que su tía, la señora Rafaela Pereira de Taillart, podía reembolsar el dinero, ${ }^{75}$ eran estos casos en que se podía suponer el perfil pudiente de algunas mujeres costarricenses con familiares en Europa. En Bolonia, el joven Juan Bernini, estudiante de medicina, pudo quedarse y proseguir sus estudios gracias a que había "obtenido amplia aseguración de crédito de parte de la Señora en cuya casa habita". ${ }^{76}$ Juan Loots decía haber "encontrado aquí [Amberes, Bélgica] una prima que tiene una tienda de calzado, y en donde estoy como en mi casa". ${ }^{77}$ Mujeres de origen o ligamen costarricense eran partícipes de diversas transacciones económicas en medio de la guerra, como el caso de doña Lydia Troyo, ${ }^{78}$ y si bien algunas eran esposas de, les antecedía un estatus de poder que, en el caso de la esposa del marqués Manuel María Peralta, la condesa belga Jehanne de Clérembault de Soer, le hacía propietaria del castillo de Kinkempois, cerca de Lieja, Bélgica, destruido por los alemanes debido a que ella había sido antes esposa de un general francés. ${ }^{79}$ Por su parte, María Antonieta Jiménez contrajo matrimonio con el aviador Charbonell cuando ella se encontraba "de paseo en la Ciudad Luz [...] en la capital francesa". ${ }^{80}$

Además de huir o de costear la sobrevivencia durante la guerra, las mujeres costarricenses participaron en ella desde ese oficio reservado al heroísmo femenino que fue la enfermería; algunas lo hicieron por hallarse en conventos de la Hermandad de la Caridad, la cual fue llamada a servir en los hospitales, como era el caso de las hermanas Teresa y Landelina Valenciano. ${ }^{81}$ La participación de mujeres costarricenses en la Cruz Roja belga fue reconocida por la prensa:

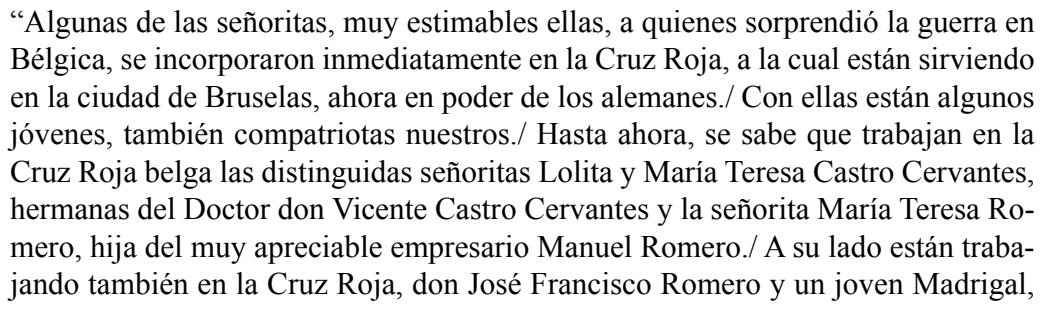

75 ANCR, Cajas de Relaciones Exteriores, Francia, 22.388, 28 de abril de 1916. Legación en París a Ministro de RREE Mariano Guardia Carazo.

76 ANCR, Cajas de Relaciones Exteriores, Italia, 22.197, 2 de octubre de 1914. Legación en Bolonia a Ministro de RREE Manuel Castro Quesada.

77 La Prensa Libre, "Carta de don Juan Loots para su señora, escrita en Amberes antes de la caída de la ciudad", 14 de octubre de 1914, 2.

78 ANCR, Cajas de Relaciones Exteriores, Francia, 22.279, 25 de octubre de 1915. Legación en París a Ministro de RREE Julio Acosta.

79 La Prensa Libre, "Esta carta, recibida ayer de España, suministra valiosas referencias de los acontecimientos europeos", 16 de octubre de 1914, 1.

80 La Prensa Libre, "El aviador Charbonell, cuya esposa es costarricense, fue herido en la Champaña", 4 de julio de 1917, 2.

81 La Información, "Dos señoritas costarricenses que han profesado en la Hermandad de la Caridad se encuentran prestando sus servicios en los hospitales franceses", 10 de octubre de 1916, 4. 
hijo de don Ramón Madrigal./ Que el hada de la ventura proteja el gesto noble de las bellas costarricenses!". ${ }^{2}$

Una carta de Roberto Madrigal desde Bélgica a su madre dibujaba una cruel atmósfera luego de la invasión alemana, pero en medio del difícil panorama, Madrigal rescataba la labor de las mujeres y confirmaba la presencia entre ellas de una costarricense al servicio de la Cruz Roja:

\begin{abstract}
"Los muertos y heridos son en millares, todo aquí está cerrado y en la más profunda tristeza. Todas las casas están a la disposición de la Cruz Roja. Yo estoy bien, comiendo sólo papas y pan, todo vale el triple [...] Miles de romeros andan en las calles llorando, rezando y cantando y hasta que ponen los pelos de punta. Las estaciones, los puentes, todo aquí está resguardado por mujeres. Todo el mundo está en la guerra./ No camina uno dos pasos, cuando se encuentra mujeres con chiquitos que le piden porque no tienen que comer y el Estado no les puede dar; y si no son mujeres las que piden, es la Cruz Roja./ Yo mismo he comprado pan para darle a los chiquitos de la playa, que con solo verles la cara se les ve la miseria en que se encuentran./ La señorita María Castro está en la Cruz Roja. Se teme el cólera, porque son muchos los muertos y no hay tiempo de quemarlos. Hace cinco días se baten sin cesar y hasta ayer los alemanes pidieron un armisticio para recoger los heridos y quemar los muertos". ${ }^{83}$
\end{abstract}

La incorporación a la Cruz Roja para las costarricenses, sin embargo, no era algo sencillo. La publicación en La Prensa Libre de las cartas enviadas desde Bélgica por Santiago Durán a su amigo Alberto Blanco en el país así lo sugiere: "El colegio de la 'Santísima Trinidad' en Lovaina, sirvió para asiento de la 'Cruz Roja' en la cual figuraron: doña Brígida Fernández de Velázquez, Jorge Müllner y J. Manuel Durán. Los servicios que ellos ofrecieron prestar no fueron utilizados por ser extranjeros, pero les cabe la satisfacción de haberse inscrito como voluntarios" ${ }^{84}$ Las limitaciones para formar parte de la Cruz Roja no solamente provenían de la condición extranjera, sino también de la formación y experiencia previas, aunque el desaliento promovido por las autoridades diplomáticas costarricenses parece haber jugado también un papel:

"La Srta. Dolores Castro hermana del Sr. D. Vicente, quiere servir como enfermera a Francia, pero carece de diploma y de práctica y aquí las enfermeras son voluntarias, algunas riquísimas que sirven gratuitamente. Las extranjeras que hay son sostenidas por los institutos que las envían./ He dicho a la Sta. Castro que en Serbia hay gran demanda de enfermeras, pero que en Costa Rica hallaría campo vasto y pro[ilegible] para su actividad". 85

82 La Prensa Libre, "Distinguidas señoritas que están al servicio de la Crus [sic] Roja en Bélgica", 9 de setiembre de 1914, 2.

83 La Prensa Libre, "Los costarricenses comiendo solo pan y papas en Europa. Una carta de Bélgica de don Roberto Madrigal", 10 de setiembre de 1914, 2.

84 Santiago Durán, "Carta de un costarricense que está en Bélgica", La Prensa Libre, 9 de setiembre de 1914, 2; Santiago Durán, "Impresiones de la guerra", La Prensa Libre, 14 de octubre de 1914, 2.

85 ANCR, Cajas de Relaciones Exteriores, Francia, 22.279, 24 de marzo de 1915. Legación de Costa Rica en París a Ministro de RREE Manuel Castro Quesada. 
Fuera de la enfermería de guerra, las mujeres costarricenses no tuvieron experiencias que les reservaran otro tipo de heroísmo. La única historia heroica divulgada por la prensa, sobre una costarricense que sufriera las consecuencias corporales del combate al otro lado del océano, fue desmentida poco después de publicada. Tanto La Información como La Prensa Libre informaron en junio de 1916 sobre una mujer llamada Romelia Salazar que, enrolada en la Cruz Roja, fue herida por una granada en el frente de Italia luego de acompañar a su esposo de origen italiano quien se enlistó para defender a su país; ${ }^{86}$ en agosto, sin embargo, La Prensa Libre publicó una carta enviada por el esposo, de apellido Zaniboni, quien aclaraba que "el herido fue él, a causa de una caída de aeroplano y que su señora enfermó de la angustia que el suceso le produjo". ${ }^{87}$

No es difícil suponer que, a este lado del océano, las vivencias de la guerra entre las mujeres incluyeron la despedida de parientes o esposos que debieron partir a apoyar a la patria de origen. En este sentido, la presencia femenina sirve para la construcción de heroísmos masculinos, y entre los varios episodios que retratan esa constante realidad entre los reservistas franceses e italianos, siempre se hizo sentir el carácter tradicional del género en el discurso de la prensa, la cual destacaba los atributos sentimentales y decorativos de las madres, hijas, hermanas, esposas o prometidas que veían partir a los suyos como soldados:

"En la estación estuvieron todos los miembros de la colonia que, por algún motivo, no han debido hacer viaje, presididos por el señor encargado de Negocios de Francia, señor de Francqueville, las esposas, madres e hijas de los que se iban y muchas señoras, señoritas y caballeros costarricenses, a quienes ligan lazos de amistad o de familia con los expedicionarios". ${ }^{88}$

"Y en medio de aquello, entre el entusiasmo, la fe y el denuedo, el triunfo sencillo de las flores que llevaron innúmeras damas italianas; y entre las flores la ofrenda cristalina de las lágrimas que esas mismas damas derramaban: tal por el hijo que pronto será lustre de la casta; la otras por el amigo que empieza a prestigiarse con el barniz de lo romancesco; y quien sabe cuántas, entre las más jóvenes, lloraban por el novio, con celos de la muerte que, al fin vieja, muestra gran preferencia por los mozos". ${ }^{89}$

86 La Información, "Una costarricense herida en el frente italiano", 4 de junio de 1916, 5; La Prensa Libre, "Romelia Salazar se llama la valiente mujer costarricense que fue herida en el frente italiano. Quién es ella", 6 de junio de 1916, 2.

87 Malvino Zaniboni, "Nos escribe de Turín el señor Zaniboni informándonos de lo ocurrido a él y a su señora”, La Prensa Libre, 28 de agosto de 1916, 2. En setiembre de 1916 el diario La Información aún no había corregido ni desmentido la noticia, sino que sostenía la versión heroica de la mujer herida oriunda de Heredia. La Información, "De la guerra. ¿Quién es la señora costarricense que fue herida en el frente italiano? Ella es una valiente herediana", 9 de setiembre de 1916, 4.

88 La Prensa Libre, "La partida de los reservistas franceses", 6 de agosto de 1914, 1.

89 La Prensa Libre, "Los italianos que se fueron", 7 de julio de 1915, 3. 
"partió el tren especial que condujo a Limón a los reservistas italianos que van rumbo a la patria./ La concurrencia de señoras, señoritas y caballeros que estuvo a despedirlos, fue numerosísima. En ella se contaban las madres, hermanas, esposas e hijas de los reservistas, lo cual motivó una serie de escenas emocionantes a todos los presentes". ${ }^{90}$

Una vez que estuvieron los reservistas en el campo de batalla, sus madres fueron felicitadas por el servicio militar de sus hijos, ${ }^{91}$ estos fueron llamados a regresar por la enfermedad de la madre, ${ }^{92} \mathrm{o}$ en otros casos debieron las madres aclarar la nacionalidad de sus primogénitos para verificar si debían o no servir al esfuerzo de guerra en la supuesta patria de origen. ${ }^{93}$ Como se apuntaba, la experiencia femenina de las mujeres costarricenses no fue unívoca: entre el huir de la guerra o quedar atrapadas en ella, el recibir apoyo económico o darlo a otros, el servir de enfermeras, ver partir a sus amados y recibir honores por ello, la guerra había traído un conjunto de vivencias posiblemente inusuales, pero que sintonizaban bien con la cambiante presencia pública de las mujeres en la sociedad costarricense. Con esto no parece haberse trastornado radicalmente el orden local de los géneros, pero sí es notable la oportunidad que tuvieron algunas de ser parte de un episodio global que trajo nuevos modos de presencia y reconocimiento sociales. Esto se reafirma considerablemente en el caso de la beneficencia.

\section{Movilización a distancia: beneficencia y caridad internacional}

La movilización de las mujeres en torno a la caridad internacional vinculada a la Gran Guerra conjugó al menos tres importantes procesos históricos en curso, como parte de las transformaciones biopolíticas de la sociedad costarricense, su gobierno de la vida e intervención consiguiente de los cuerpos. En primer lugar, la confluencia de distintos saberes en proceso de institucionalización como la estadística y la medicina llevó a un diagnóstico sobre la "miseria fisiológica" del país, materializada en preocupantes cifras de mortalidad infantil que ocasionaban constantes interpelaciones de estadígrafos a médicos e higienistas. ${ }^{94}$ En segundo lugar, la intervención consecuente sobre los cuerpos de mujeres y niños condujo tanto a una creciente sensibilización sobre la infancia ${ }^{95}$ como a un refuerzo del valor social de la maternidad, de modo que las mujeres, desde espacios como la filantropía

90 La Prensa Libre, "La despedida de los reservistas italianos", 6 de agosto de 1915, 3.

91 La Prensa Libre, "Los italo-costarricenses en la guerra", 27 de octubre de 1916, 2.

92 ANCR, Cajas de Relaciones Exteriores, Francia, 22.388, 1 de diciembre de 1916. Legación de Costa Rica en París a Ministro de RREE Manuel Castro Quesada.

93 ANCR, Cajas de Relaciones Exteriores, Estados Unidos, 22.484, 10 de agosto de 1917. Cónsul de Los Ángeles, California, a Ministro de RREE.

94 Dennis Arias Mora, Héroes melancólicos y la odisea del espacio monstruoso. Metáforas, saberes y cuerpos del biopoder (Costa Rica, 1900-1946) (San José, Costa Rica: Arlekín, 2016), 45-105.

95 Sobre esto véase David Díaz Arias (ed.), Historia de la infancia en la Costa Rica del siglo XX (San José, Costa Rica: Editorial Nuevas Perspectivas, 2012). 
católica y la liberal o las campañas escolares de higiene, fueron protagonistas de esa pedagogía corporal. ${ }^{96}$ En tercer lugar, era este un período de complejas transformaciones en torno a la percepción y performatividad de los cuerpos femeninos: disputas por los cánones de belleza, difusión gráfica y textual de esos modelos, desarrollo de la cultura física, vigilancia policial y médica sobre la moralidad del cuerpo de la mujer, incursión femenina en la literatura y problematización literaria sobre la vulnerabilidad social de su anatomía, eran parte de tal proceso. ${ }^{97}$

De esta manera, cuando la prensa nacional difunde noticias sobre la guerra y las actividades filantrópicas internacionales de las mujeres, debe considerarse que las damas de sociedad tenían ya una experiencia en la materia de al menos dos décadas, y que tales eventos pusieron en escena aquellos cambios sociocorporales en desarrollo, lo cual hace comprensible que las iniciativas locales no dependan en su inicio de los estímulos y las formas de la caridad internacional; no obstante, es importante resaltar el hecho de que, con la incursión de la beneficencia de las mujeres costarricenses en ese escenario global, se inaugura una forma de movilización internacional que será determinante en la historia de las mujeres y su relación con las principales guerras del siglo XX en el mundo. ${ }^{98}$

Noticias sobre la caridad internacional en torno a la Gran Guerra fueron publicadas entre 1915-1916 en la prensa costarricense. "Damas millonarias" en Estados Unidos auxiliaron a la Cruz Roja; familias y talleres constituyeron sociedades "para fabricar prendas de lana abrigadas" en Francia e Inglaterra; y las "dulcísimas y serenas" Hermanas de la Caridad también se llenaron de "sentimiento patrio" en Italia. ${ }^{99}$ Desde antes, sin embargo, se detectan actividades de beneficencia en la sociedad costarricense; tan temprano como en noviembre de 1914 fue creado un comité en Alajuela para socorrer con fondos "a las familias de la heroica tierra de los belgas", para lo cual se organizaría una velada con "la mayoría de los intelectuales alajuelenses". ${ }^{100}$ Fundamental en el inicio de las actividades de beneficencia en el país fue el esfuerzo de las mujeres de las comunidades extranjeras de países beligerantes; las italianas, por

96 Arias Mora, Héroes melancólicos..., 337-345.

97 Véase, por ejemplo, Alvarenga Venutolo, Identidades en disputa; Mora, Rompiendo mitos...; Dennis Arias Mora, "Las obsesiones corporales de Carmen Lyra entre la mirada biopolítica, el saber literario y las metáforas del poder", Cuadernos Inter.c. a.mbio sobre Centroamérica y el Caribe (Costa Rica) 11, n. 1 (enero-junio, 2014): 103-125, URL: https://revistas.ucr.ac.cr/index.php/intercambio/article/view/14236/13528.

98 Sobre las mujeres y el antifascismo costarricense frente a la Guerra Civil Española (1936-1939), véase Dennis Arias Mora, "Grabar los cuerpos y la muerte. Mujeres comunistas, maternidad de estado y el trazo fantasmal de la guerra en Emilia Prieto", en: Poéticas y políticas de género. Ensayos sobre imaginarios, literaturas y medios en Centroamérica, (eds.) Mónica Albizúrez Gil y Alexandra Ortiz Wallner (Berlín, Alemania: Edition Tranvía-Verlag Walter Frey, 2013), 189-214; Dennis Arias Mora, "Carmen Lyra: escenarios políticos, culturales y subjetivos en la era antifascista", Revista de Ciencias Sociales (Costa Rica) 120 (2008): 65-79, DOI: https://revistas.ucr.ac.cr/index.php/sociales/article/view/10773.

99 La Información, "Labores filantrópicas", 30 de enero de 1915, 1; Paul Margueritte, "Las guerras modernas y las hecatombes. Los servicios sanitarios y los heridos", La Información, 25 de marzo de 1915, 5; La Prensa Libre, "Carta que escribe a un pariente en Costa Rica una Hermana de la Caridad italiana", 22 de marzo de 1916, 2.

100 La Prensa Libre, "En Alajuela se organizan fiestas de beneficencia para socorrer a las familias de los Belgas", 9 de noviembre de 1914, 3 . 
ejemplo, desde noviembre de 1915 gestionaron el envío de ropa a las tropas de su patria de origen, ${ }^{101}$ ello significó realizar una suscripción voluntaria con la cual se compraron lanas que fueron convertidas en abrigos, medias y camisetas dirigidas a Los Alpes, lo que significó la publicación de los agradecimientos de soldados italianos. ${ }^{102}$

Numerosas actividades fueron organizadas para colaborar con las secciones italiana, rusa, inglesa, francesa y alemana de la Cruz Roja desde 1916. Así lo hizo la colonia alemana al organizar una feria. ${ }^{103}$ Donación de todo tipo de regalos, rifados luego en veladas dentro de algún teatro, fueron algo común para apoyar a esa institución italiana; tales veladas eran coordinadas por mujeres y eran estas las que les daban contenido con diversas presentaciones: recitales literarios, coros de señoritas y números de canto. ${ }^{104}$ Estas actividades tuvieron un alto perfil social y político: la fiesta en apoyo a la Cruz Roja rusa estuvo bajo la tutela de la Emperatriz de Rusia y del delegado de la Cámara de Comercio Ruso-Americana: ${ }^{105}$ las funciones de gala a beneficio de la Cruz Roja inglesa en el Teatro Variedades contaron con la presencia de "altas personalidades del gobierno, apreciables familias de nuestra sociedad y miembros prominentes de las colonias extranjeras". ${ }^{106} \mathrm{El}$ mismo perfil tenían las actividades realizadas para la sección francesa de la Cruz Roja, con la particularidad de que las actividades se extendieron por diversos puntos de la provincia de Alajuela, además de la capital San José, y de que incluyeron eventos deportivos como encuentros de fútbol masculino y de baloncesto entre señoritas de la Escuela Normal de Heredia, ${ }^{107}$ justo cuando tal deporte apenas comenzaba a conocerse en el país. ${ }^{108}$

101 La Prensa Libre, "Un grupo de señoras y caballeros de esta capital ha enviado a los soldados italianos gran cantidad de ropas", 22 de noviembre de 1915, 3.

102 La Prensa Libre, "En expresivas cartas recibidas en esta capital los alpinos italianos agradecen el envío de ropas que les hizo Costa Rica", 3 de abril de 1916, 2.

103 La Prensa Libre, "La colonia alemana prepara una feria", 20 de noviembre de 1915, 2.

104 La Prensa Libre, "Se hacen muchos preparativos para la velada a favor de la Cruz Roja italiana", 11 de agosto de 1916, 2; La Prensa Libre, "Más de $₫ 1.500$ en obsequios han sido enviados para las rifas de mañana durante la función a beneficio de la Cruz Roja italiana", 10 de noviembre de 1916, 2; La Prensa Libre, "El espléndido festival del sábado a beneficio de la Cruz Roja Italiana", 13 de noviembre de 1916, 2.

105 La Prensa Libre, "Habrá una fiesta patriótica en el Trébol, el lunes próximo, a beneficio de la Cruz Roja Rusa", 7 de octubre de 1916, 2.

106 La Prensa Libre, "Mañana comenzarán en el Variedades las funciones de gala a beneficio de la Cruz Roja inglesa", 6 de junio de 1917, 2; véase también La Prensa Libre, "Fue una verdadera función de gala por la exhibición de las vistas de la guerra", 8 de junio de 1917, 2.

107 La Prensa Libre, "El Padre Santo y los niños belgas", 24 de diciembre de 1916, 5; La Prensa Libre, "La Colonia Francesa prepara un festival a beneficio de la Cruz Roja de su país, pero ha dispuesto posponerlo para el mes próximo", 19 de diciembre de 1916, 2; La Prensa Libre, "La próxima feria a favor de la Cruz Roja Francesa", 26 de julio de 1917, 3; La Prensa Libre, "La noble solicitud de las damas que forman parte del Comité de la Feria para la Cruz Roja Francesa", 13 de setiembre de 1917, 2; La Prensa Libre, "La Cruz Roja Francesa en Alajuela", 20 de setiembre de 1917, 2; La Prensa Libre, "Los palmareños enviarán un valioso contingente a la Feria de la Cruz Roja Francesa", 3 de octubre de 1917, 2; La Prensa Libre, "Para no restar público a la Feria se pospone hasta nueva orden la manifestación de los aliados a favor de la ruptura de relaciones", 6 de octubre de 1917, 2; La Prensa Libre, "La espléndida y generosa fiesta celebrada el sábado y el domingo. Alcanzó un éxito notable la Feria de la Cruz Roja Francesa", 8 de octubre de 1917, 2; La Prensa Libre, "Costa Rica a Francia. Mañana en La Sabana”, 13 de octubre de 1917, 2.

108 Chéster Urbina, Costa Rica y el deporte (1873-1921): un estudio acerca del origen del fútbol y la construcción de un deporte nacional (Heredia, Costa Rica: EUNA, 2001). 
No hay mayores diferencias con respecto a lo anterior al revisar las actividades desarrolladas en favor de los niños belgas desde 1916, luego de la invasión alemana a su territorio. Funciones de gala en teatros y veladas artísticas fueron promovidas y protagonizadas por mujeres en San José, Heredia y Cartago, en ocasiones apoyadas o motivadas por autoridades eclesiásticas ${ }^{109} \mathrm{o}$ incluso por los mismos periódicos, como fue el caso del diario La Información. ${ }^{110}$ Lo destacable de esta movilización a distancia para socorrer a los huérfanos de Bélgica está menos vinculado con lo sucedido en los campos de Flandes, que con el cambio en la política interna costarricense. Luego de una severa crisis económica motivada por la interrupción del comercio exterior afectado por la guerra y las reformas fiscales consiguientes promovidas por la administración de Alfredo González Flores (1914-1917), su Secretario de Guerra, Federico Tinoco le dio un golpe de Estado después del cual fungió como gobernante entre 1917-1919; poco después del golpe de enero de 1917, la esposa de Tinoco, María Fernández de Tinoco, una escritora, arqueóloga y teósofa, sería quien lideraría la conformación de los comités encargados de administrar los fondos para la ayuda de los niños belgas, un hecho trascendental por la reveladora composición social, política e intelectual del Comité principal.

El 22 de marzo de 1917, con el objetivo de secundar la obra benéfica de la Princesa de Ligne y de su delegado el señor Alex de Wind, se constituyó el Comité de Damas para socorrer a niños belgas pobres, heridos y refugiados; la Junta Directiva tenía entre sus presidentas honorarias a María Fernández de Tinoco, entre las vicepresidentas a Adela de González Víquez, como presidenta efectiva a Marian Le Capellain, como vicepresidenta efectiva a Mercedes Lara de Tinoco, como segunda secretaria a Esther de Mezerville, y entre sus vocales honorarias a Ana María de Brenes Mesén y Anita de Fernández Guardia. ${ }^{111}$ A criterio del delegado

109 La Información, "Por los niños belgas", 23 de agosto de 1916, 5; La Prensa Libre, "La velada de esta noche en Cartago a beneficio de los pobres niños belgas", 17 de noviembre de 1916, 2; La Prensa Libre, "Una fiesta en Cartago para recaudar fondos para los niños huérfanos de la heroica Bélgica”, 18 de noviembre de 1916, 3; $L a$ Prensa Libre, "La gran velada del sábado próximo, en el Teatro América, a beneficio de los niños belgas", 21 de noviembre de 1916, 2; La Prensa Libre, "Las localidades de la velada por los niños belgas", 29 de noviembre de 1916, 2; La Prensa Libre, "La sociedad herediana y los niños belgas", 19 de diciembre de 1916, 2.

110 La Información, "Por los huérfanos de la guerra", 24 de enero de 1915, 4; La Información, "Un rasgo", 28 de octubre de 1916, 5.

111 La Prensa Libre, "La organización de las Fiestas Belgas", 23 de marzo de 1917, 2. La composición completa según la prensa fue: Presidentas Honorarias doña María Fernández de Tinoco, doña María Pontón de Arce de Echeverría; Vicepresidentas Honorarias doña Adela de González Víquez, doña Felicia de Pacheco; Presidenta Efectiva señorita Marian Le Capellain; Vicepresidenta Efectiva doña Mercedes Lara de Tinoco; Primera Secretaria doña Deidamia C. de Esquivel; Segunda Secretaria señorita Esther de Mezerville; Tesorera doña Luisa M. de Anderson; Vocales Honorarias doña Marta de Lara, doña Isabel de la G. de Jiménez, doña Clementina de Quirós, doña Lastenia de Johanning, doña Ana María de Brenes Mesén, doña Pacífica de Soto, doña Anita de Fernández Guardia, doña Joaquina de Castro, doña Anita H. de Jiménez, doña Adela Gargollo de Jiménez, doña Zelmira de Capella, doña Edith de Povedano, doña Luisa M. de Jiménez, doña Isabel B. de Rojas; Damas Auxiliares señoritas Lolita Pacheco, Lelia Alvarado, Amalia Chavarría, Margarita Chavarría, Consuelo y Enriqueta Yglesias, Margarita Segreda, Chava Mangel, Adelia Carranza, Clemencia y Marta Montealegre, Margarita Pittier, Eugénie Gallegos, Graciela Villafranca, Haydée Alvarado, Marta y Clementina Medal, Celia y Clotilde Saborío, Rosalía y Julia Lara. 
de la Princesa de Ligne, el Sr. Wind, la constitución de ese Comité de Damas se debía a la gestión de María Fernández de Tinoco. ${ }^{112}$ Semejante composición permite confirmar la vinculación entre el desarrollo conjunto de la política social liberal y la filantropía, con el ingreso de esta a la caridad internacional de la guerra; Fernández de Tinoco y Le Cappellain habían conformado la primera Junta Directiva del programa La Gota de Leche (1913) ${ }^{113}$ y Adela de González Víquez había participado en algunas tareas del programa, entre otras múltiples actividades benéficas, así como era esposa de Cleto González Víquez, cuya primera administración presidencial entre 1906-1910 fue central en la extensión y en la estandarización internacional de obras higienistas. ${ }^{114}$

El Comité de Damas por los niños belgas se extendió y realizó actividades en provincias como Alajuela, Heredia y Limón; ${ }^{115}$ asimismo, tuvo la particularidad de que, en un momento de severa crisis socioeconómica en el país por el contexto de guerra, procuró evitar gastos en trajes de lujo para las mujeres, "en armonía con la situación económica general", ${ }^{116}$ mientras los recursos conseguidos para la caridad internacional fueron dirigidos también a los pobres del país, pues: "Tenemos que hacer algo por los belgas, pero en las actuales circunstancias, no podemos olvidar un momento a nuestros hermanos en desgracia que viven en el mismo país". ${ }^{117}$ De hecho, se publicaron los montos recaudados luego de un baile de mantones en el Teatro Nacional, especificando las sumas totales por provincia, así como la parte dedicada a esos pobres. ${ }^{118}$

112 La Prensa Libre, "Carta del Sr. Alex de Wind”, 31 de marzo de 1917, 2. Entre la correspondencia consular de la Legación en París existían sospechas de que Alex de Wind trabajaba para los alemanes y se dudaba del modo en que había conseguido la nacionalidad belga; sin embargo, en la documentación de la Secretaría de Relaciones Exteriores costarricense no hay otros registros que permitan dar seguimiento y corroboración a estas sospechas. Véase ANCR, Cajas de Relaciones Exteriores, Francia, 22486, 30 de marzo de 1917. Legación en París a Ministro de RREE Lic. Carlos Lara.

113 Ana María Botey Sobrado, "Infancia, alimentación y filantropía en Costa Rica: La Gota de Leche (1913)", en: Díaz Arias (ed.), Historia de la infancia..., 17-61.

114 Arias Mora, Héroes melancólicos..., 64.

115 La Sección de Limón contó con Jessy de Chittenden, doña A. María de Mora Fernández, doña Evangelina de Mora Fernández, y la de Alajuela con la de Fidelina de Cortés. La Prensa Libre, "La instalación del Comité de señoras de Alajuela y Limón para el socorro de los belgas", 3 de abril de 1917, 2; La Prensa Libre, "Las fiestas que se preparan en Heredia a beneficio de los belgas", 4 de abril de 1917, 2; La Prensa Libre, "Gran Baile de Verbena en el Teatro Nacional", 19 de abril de 1917, 2; La Prensa Libre, "El Comité de damas pro-Bélgica en Heredia", 23 de abril de 1917, 2.

116 La Prensa Libre, "Las comisiones de damas y caballeros para el baile de mantones del próximo sábado en el Teatro Nacional", 16 de abril de 1917, 2.

117 La Prensa Libre, "El producto del baile de mantones de mañana en la noche en el Teatro Nacional se dividirá por iguales partes entre los pobres de Costa Rica y los niños desamparados de Bélgica", 20 de abril de $1917,1$.

118 La Prensa Libre, "Las señoras que integran el Comité pro-belga se reunieron ayer para resolver la inversión de los fondos", 4 de mayo de 1917, 2. El producto obtenido fue el siguiente: San José, £3.176,75; a los pobres de esta provincia, $\varnothing 1.858,40$. Heredia, $₫ 262,55$; a los pobres, $\varnothing 1.588,40$-así lo consigna la fuente; sin embargo, es probable que fuera solo la mitad de los 262,55 colones- ${ }^{-}$. Limón, $₫ 1.107,30$; a los pobres, $ф 553,65$. Alajuela, $ф 124$; a los pobres $\phi 62,00$. 
La dimensión de género y de clase en esta forma de movilización a distancia es notable; mujeres de clases media y alta desarrollaron numerosas actividades de beneficencia que se integraron a la caridad internacional de la guerra. Fuera de sus propios esposos o familiares, la participación organizadora y performativa de otros hombres es menos visible en las fuentes; de esto se exceptúa un grupo de obreros que también creó un Comité pro-belga cuya junta directiva estaba compuesta solo por hombres, entre ellos el catalán y antiguo editor de la revista anarquista Renovación, Ricardo Falcó. ${ }^{119}$ Este Comité organizó un mitin para el $1^{\circ}$ de mayo de $1917,{ }^{120}$ pero no es posible seguir la pista de otras actividades en la prensa; presuntamente, el Comité se había ausentado de una partida de fútbol organizada para recoger dinero en favor de los obreros belgas, actividad de la que el presidente Tinoco se había excusado de asistir por motivo de enfermedad, estando en su lugar el Secretario de la Comandancia en jefe y su hermano el Secretario de Guerra Joaquín Tinoco; ${ }^{121}$ la fuente no permite saber si tales ausencias eran señal de distanciamiento entre los grupos obreros y el gobierno golpista, pero el descontento por la crisis económica y la especulación, que en noviembre de 1917 llevó a la organización del primer Congreso Obrero de la Confederación General de los Trabajadores, así lo sugiere. ${ }^{122}$ Por lo demás, en medio del predominante liderazgo femenino de la caridad, algunos hombres como el escritor José María Zeledón, también de trayectoria anarquista, leyeron su poesía en una velada en favor de los huérfanos de la guerra en el Teatro Nacional, mientras otros caballeros destacaron por sus donativos al "Hogar de los Huérfanos Belgas", ubicado en La Haya, Holanda. ${ }^{123}$ Durante las manifestaciones organizadas con motivo del final de la guerra en noviembre de 1918 reaparecen las líderes de la caridad acompañadas por sus esposos para celebrar la paz mundial. ${ }^{124}$

Territorio privilegiado del liderazgo femenino, la caridad internacional en el país canalizó una importante trayectoria social de las mujeres en la filantropía y la política social liberal y católica, así como abrió distintos escenarios donde performativizar la palabra, los cuerpos y esa solidaridad teñida de maternalismo frente a la orfandad del mundo. No debe perderse de vista un dato fundamental: la consolidación de esta movilización a distancia ocurre a la sombra del poder, en el tránsito del

119 La Prensa Libre, "Las labores del Comité especial obrero pro-belga", 21 de abril de 1917, 2. Sobre Falcó, véase Flora Ovares, Crónicas de lo efimero. Revistas literarias de Costa Rica (San José, Costa Rica: EUNED, 2011), 81, 146.

120 La Prensa Libre, "Sigue trabajando decididamente el Comité Especial Obrero pro-belga", 25 de abril de $1917,3$.

121 La Prensa Libre, "El match de ayer en La Sabana fue ganado por el teams Bélgica", 19 de mayo de 1917, 2.

122 Vladimir de la Cruz, Las luchas sociales en Costa Rica (1870-1930) (San José, Costa Rica: EUCR, 2004), 91.

123 José María Zeledón, "Los pobres niños", n. 28, Colección EOS (abril, 1917): 146; La Información, "Por los huérfanos belgas", 19 de mayo de 1918, 2.

124 La Prensa Libre, "Una fiesta de la paz", 16 de noviembre de 1918, 2; La Prensa Libre, "Para celebrar la paz universal", 27 de noviembre de 1918, 2; La Información, "La celebración de la paz y la victoria en Costa Rica", 12 de noviembre de 1918, 4. 
golpe de Estado a la dictadura, ¿cómo afectó esto al feminismo en ciernes? ¿Cómo se entrecruzan la Gran Guerra y el origen de la causa feminista costarricense?

\section{La guerra en los orígenes del feminismo}

Si bien para 1914 el incipiente feminismo costarricense parecía tener dos vertientes: una liberal por la igualdad de derechos, y la otra obrera y social reformista, es en la primera en donde, de momento, pueden documentarse mejor los efectos de la Gran Guerra, siguiendo el rastro de los primeros pasos en la vida intelectual de Ángela Acuña. No mucho después de iniciada la conflagración, los reportes consulares y los medios de prensa informaron sobre la presencia del hermano de Acuña, el ingeniero Jorge Acuña Braun, en la Bélgica sitiada por los alemanes. Jorge Acuña aparecía entre la correspondencia diplomática como uno de los varios costarricenses que, desprovisto de recursos, era necesario repatriar. ${ }^{125}$ Entre enero y febrero de 1915 fueron publicados los relatos del ingeniero, "testigo presencial del sitio de Lieja", donde contaba sobre la ocupación alemana del castillo de Kinkempois en que residía el diplomático costarricense Manuel María Peralta, ${ }^{126}$ o sobre las arbitrariedades del ejército alemán como el llevar a una familia belga a los tribunales "por el delito de no permitir al jefe de un cuerpo prusiano el deshonrar una respetable señorita". ${ }^{127}$

Por entonces, Ángela Acuña, quien había iniciado su vida intelectual participando en algunas revistas y veladas literarias, escribe sus primeros artículos sobre la guerra. No hay indicios de que su abordaje del tema fuera influido por los testimonios del hermano, a pesar de que ella había estado años antes en el castillo de Kinkempois bajo la hospitalidad del marqués de Peralta, ${ }^{128}$ o de que ella misma recordara que ya para 1912 habían iniciado sus "luchas emancipadoras" por la causa sufragista. ${ }^{129}$ Sus artículos de setiembre de 1914 y febrero de 1915 no ofrecen indicador alguno de una lectura en clave feminista de la guerra; más bien ella se posiciona como figura ilustrada haciendo referencia a sus mentores, mostrando preocupaciones civilizatorias, humanistas y cristianas, y explicaciones darwinistas comunes a su medio intelectual, proponiendo una conciencia ilustrada como eje idealista para un futuro sin guerra:

125 ANCR, Cajas de Relaciones Exteriores, Inglaterra, 22.191, 6 de setiembre de 1914. Legación en Londres a Ministro de RREE Manuel Castro Quesada.

126 Jorge Acuña Braun, "Un testigo presencial del sitio de Lieja. Interesante relato del Ingeniero don Jorge Acuña Braun”, La Información, 26 de enero de 1915, 6.

127 Jorge Acuña Braun, "Testigo presencial del sitio de Lieja. Interesante relato del Ingeniero D. Jorge Acuña Braun”, La información, 4 de febrero de 1915, 3.

128 Según la escritora Yadira Calvo, la visita de Ángela Acuña al castillo fue en 1909, en medio de sus estudios secundarios en el continente europeo. Calvo, 45-52.

129 Ángela Acuña, La mujer costarricense a través de cuatro siglos. Tomo II (San José, Costa Rica: Imprenta Nacional, 1970), 343. 
"A mi maestro el Dr. Don Alejandro Rivas Vázquez./ La civilización, que trae consigo el refinamiento de todas las pasiones que agitan el mundo, no hace más, para paliar la acerbidad de estas, que adormecer a nuestros instintos brutales./ Hay momentos en la vida en que el alma se desborda, en que el espíritu estalla, porque necesita dar una salida a sus pasiones. He aquí por qué se comprende que los pueblos tan civilizados como los de Europa se lancen iracundos, con gesto furioso, a la conquista, en pleno siglo XX; y con este propósito se agitan audaces - podríamos decir hasta sublimes- en su furia diabólica, afiebrados como la tierra que germina./ Suprimir el combate no es posible [...] ¡La Guerra! Esta palabra que nos llena de confusión y de misterio, que locamente ha palpitado a través de las edades, no es más que una consecuencia natural de la vida [...] hay que desengañarse. El mundo no puede aspirar todavía a la concordia, porque no ha alcanzado el alto nivel que las enseñanzas cristianas le marcan, para hacerse capaz de aquella excelsa virtud [...] La marcha levantada de los acontecimientos políticos y sociales en las postrimerías del siglo pasado y en los comienzos de este, hizo concebir a Andersen la idea de fundar una ciudad ideal, con objeto de reunir en ella, como en haz de intelectualidad asombrosa, la conciencia ilustrada y generosa del mundo, para hacer de los hombres todos un conglomerado de individuos dichosos, fuertes y bellos./ Hermoso idealismo que viene a enfrentarse cara a cara con la fuerza bruta, que es el salvajismo puesto actualmente en acción en los pueblos de la Vieja Europa. Aquel centro de paz universal se levantará algún día airoso, entre refulgentes aureolas, pregonando a los cuatro vientos sus luminosas teorías.../ Por desgracia, repito que los tiempos no están aún maduros para ese hermosísimo ideal, y la guerra prevalecerá todavía entre los hombres, quizá no por décadas, sino por siglos". ${ }^{130}$

\section{Al lado de esa aparente estrategia de posicionamiento intelectual, en un} ambiente de mentores masculinos propensos algunos al apoyo de causas feministas, es importante destacar de estos primeros textos de Acuña la neutralidad asumida frente al conflicto internacional. Entre diversas metáforas orgánicas sobre la política y la guerra, comunes en su medio cultural y en sus lecturas, ella tomaba distancia sobre cualquier bandera y mostraba cierta sensibilidad por los hijos y esposas de soldados abatidos:

“[...] los que estamos alejados de la lucha presente, debiéramos mirar ésta con dolor, sin tomar bandería por ninguno de los luchadores, que todos son hermanos nuestros, representantes de la civilización de que tanto nos enorgullecemos [...] Sea como fuere, de esta guerra -que todos deploramos por los huérfanos y las viudas que en pos de sí va a dejar en profunda desgracia- debemos esperar algo que será reconfortante para las sociedades humanas. Algunos estadistas, que son los que más han llamado mi atención para dedicar a ellos mis horas de estudio, creen que las sociedades humanas son como jardines, cuyas plantas es preciso podar de tiempo en tiempo, empleando la cuchilla para suprimir en ellas las ramas inútiles. Si eso es verdad, como yo no lo dudo, en el orden inflexible de la naturaleza, la guerra tendría su razón humana y divina de ser. Yo no lo sé; pero si sé que el huracán que pasa y destruye, fecunda al mismo tiempo lo que deja con vida; siembra momentáneamente la desolución [sic], pero prepara la tierra a una fertilidad nueva, renovada y fuerte". ${ }^{131}$

130 Ángela Acuña, "La persistencia fatal de la guerra", La Prensa Libre, 25 de setiembre de 1914, 2. 131 Ángela Acuña, "Las consecuencias de la guerra", Fígaro, 3 (25 de febrero de 1915): 42. 
A partir de 1916 Acuña mostrará un cambio de posición al reflexionar sobre la guerra; se alejará de la neutralidad e incursionará en el escenario de las movilizaciones femeninas por la caridad internacional. Es muy probable que en esto influyera, como se retoma más adelante, la difusión en prensa de las actividades pacifistas del feminismo internacional; en mayo de 1915, como se aprecia en la fotografía 9 del cuadro, se divulgó en La Información el viaje de las delegadas feministas estadounidenses hacia la Conferencia Internacional por la paz en La Haya, Holanda, y quienes sostenían: "We women can and must end the war in Europe, and we are going to stop it, though the stopping cost us our lives". ${ }^{132}$ Si bien no con tanto radicalismo, Acuña mantuvo un perfil intelectual en aquellas actividades de beneficencia, siguiendo la línea performativa desplegada en las veladas literarias del Ateneo desde 1912. ${ }^{133}$ En agosto de 1916 participó en el homenaje a las naciones aliadas realizado en el Teatro América de la capital; dejando atrás la reivindicación de la neutralidad, la participación de Acuña fue destacada como "nota sobresaliente" de la función, en la cual aparecían "bellas señoritas" representando a las diferentes naciones, mientras ella daba un discurso relativo a cada uno de esos aliados:

\begin{abstract}
"Rusia despierta de su letargo, gloriosamente, entre los vítores de triunfo con que la aclama el mundo [...] ¡Paso a la Italia vencedora! ¡Salve Madre del Arte y del ensueño! ¡Tus triunfos serán un poema de glorificación infinita! Llenas nuestra vida con el recuerdo magnífico de tu historia, con el encanto de tus poetas divinos en los primeros tiempos de ella, con los lirismos ardientes de los que vinieron en generaciones nuevas, con tu arte excelso que en ninguno de los órdenes de la estética espiritual ha sido jamás superado por ningún pueblo [...] La severa y taciturna Inglaterra, la orgullosa ALBION, emperatriz de los mares, representante hoy de lo que fue un tiempo el Fausto Imperio de Carlos V, en cuyos dominios no se ponía el sol, ha sido durante los tres siglos recientemente pasados, y continúa siendo aún el nido verdadero de la libertad, de la fraternidad, de la justicia y del derecho. Las grandes ideas humanas han tenido su incubación y pleno desarrollo en esa Inglaterra, que marcha hoy a la cabeza de las naciones del mundo [...] Es Francia quien lleva entre vítores y triunfos la antorcha viva de las civilizaciones todas, y en sus entrañas ardientes vibra enardecido el sentimiento de patria, de dignidad y de progreso; y de esas entrañas orgullosas brotaré el verbo anhelado de la verdadera democracia [...] La liquidación del vértigo presente en que se agita hoy la Europa, no podrá ser sino el triunfo definitivo de Francia, de esa Francia feliz, cuna del genio, segunda madre nuestra, por la cual arde en nuestros corazones alta la llama del más puro y admirable afecto [...] En nombre de nuestra valerosa e inteligente raza latina, saludemos a la admirable Bélgica; por ella vibran con sonoro ritmo de entusiasmo todas las fibras de mi alma". ${ }^{134}$
\end{abstract}

132 "Nosotras las mujeres podemos y debemos terminar la guerra en Europa, y vamos a detenerla, aunque esto nos cueste nuestras vidas". Traducción propia. La Información, "Isar's Troops drive German T[ilegible]", 8 de mayo de $1915,8$.

133 Acuña, La mujer costarricense a través de cuatro siglos. Tomo II, 345.

134 La Información, "Homenaje a las naciones aliadas", 28 de agosto de 1916, 4. 
Como se anotara en el apartado anterior, el protagonismo femenino en tales actividades era considerable; las mujeres encontraban allí un nuevo espacio público donde demostrar distintos talentos, y el de Acuña estaba relacionado con el pensamiento y las letras. En un festival a beneficio de la Cruz Roja italiana, en noviembre de 1916, se destacaba nuevamente su participación en medio de números de canto y recitales:

\begin{abstract}
"El teatro estaba completamente lleno con selecta concurrencia. Un grupo de señoritas, vestidas con trajes de la Cruz Roja, recogían dinero en huchas que llevaban colgando al cinto y vendían números para las rifas de regalos, flores, banderas italianas, etc., lo cual produjo, según nos han informado, una buena suma de dinero. Entre los regalos recibidos que fueron muchos, los había de verdadero mérito por su valor o por lo delicado del trabajo [...] Una nota simpática en sumo grado fue el número literario a cargo de la señorita Angela Acuña quien con vibrantes frases habló de la heroica Tierra del Arte en donde siempre ha flameado una bandera gloriosa bajo un cielo de libertad nunca oscurecido". ${ }^{135}$
\end{abstract}

Otro festival artístico se realizó el mismo mes en beneficio de los niños belgas, y allí aparecía Ángela Acuña como parte de los distintos actos efectuados. ${ }^{136}$ Quiere decir que, además de posicionarse desde la actividad intelectual y de abandonar la neutralidad, Acuña incursionó en el mundo femenino de la beneficencia josefina, la caridad internacional y su dimensión maternalista. Esto hace muy llamativo el hecho de que en su reconocida obra en dos tomos, $L a$ mujer costarricense a través de cuatro siglos (1970), existieran tan pocas referencias a la guerra y al protagonismo femenino en ella, y ninguna en concreto con respecto a las movilizaciones de las mujeres dentro de ese escenario de la caridad internacional de la Primera Guerra Mundial. ¿Por qué no hay un lugar para las mujeres costarricenses de la Gran Guerra en el recuerdo de quien fuera la principal dirigente de la Liga Feminista creada en 1923?

De los efectos de la Primera Guerra Mundial en Costa Rica hay solo dos referencias en La mujer costarricense; hablando de las mujeres viajeras, Acuña recordaba la figura de Ana Wahle de Lara, cuya "salida de Bélgica, con motivo de la Guerra de 1914 dejó en su memoria de niña horribles impresiones de terror". ${ }^{137}$ La otra referencia alude a la revista Fígaro que Acuña fundara en 1915; en ella había publicado su temprana posición neutral frente a la guerra, pero fue esta la que "nos dejó sin papel satinado y fue preciso, muy a mi pesar, suspender la publicación de Fígaro". ${ }^{138} \mathrm{Si}$ bien Acuña aludió a la Liga Internacional de Muje-

135 La Prensa Libre, "El espléndido festival del sábado a beneficio de la Cruz Roja Italiana", 13 de noviembre de 1916, 2.

136 La Prensa Libre, "El brillante festival artístico del próximo sábado por los niños belgas", 22 de noviembre de 1916, 2.

137 Acuña, La mujer costarricense a través de cuatro siglos. Tomo II, 132.

$138 \mathrm{Ibid}, 349$. 
res pro Paz, solo hizo mención del Congreso por la paz en La Haya, convocado y efectuado en 1915; aparentemente el "deseo de poner fin a los horrores de la guerra" llevó en 1919 a transformar el Comité Internacional de Mujeres pro Paz Permanente en una Liga Internacional de Mujeres pro Paz y Libertad, que empezó como "entidad internacional y después organizó secciones nacionales", pero no hay referencias en el libro, ${ }^{139}$ tampoco se ha ubicado alguna documentación de archivo que permita comprobar la existencia de una de esas secciones en el país.

La respuesta sobre el vacío en el recuerdo de Acuña con respecto a la vivencia de las mujeres durante la Gran Guerra parece vincularse con el contexto político que marcó al país luego de 1917. En ese año la movilización de las mujeres dentro de la caridad internacional de la guerra quedó inscrita dentro del nuevo orden instaurado por el gobierno golpista de los Tinoco; fue la nueva primera dama, María Fernández de Tinoco, quien lideró en adelante las actividades benéficas. La cercanía de Acuña con esta figura y su entorno político e intelectual ofrece considerables indicios de que ella fue parte del proceso de "perdón y olvido", ${ }^{140}$ luego de la caída de la dictadura tinoquista. De hecho, la biografía escrita por Yadira Calvo indica que las amigas Ángela Acuña y María Fernández de Tinoco calificaron de "bárbaros y traidores" a quienes se levantaban contra el régimen, ${ }^{141}$ por lo que el historiador Iván Molina ubica a Acuña como una de las "mujeres tinoquistas" que formó parte de aquel "proceso conciliatorio". ${ }^{142}$

Cuando Ángela Acuña recordaba en su principal obra las primeras publicaciones que hiciera en la prensa y en las revistas sobre los derechos de las mujeres y la mujer moderna, María Fernández de Tinoco aparecía también como una de esas defensoras, así como autora en la revista Fígaro editada por Acuña. ${ }^{143}$ Más aún, Fernández era reconocida como una eminente escritora, pintora y arqueóloga; Acuña rescataba de ella su labor filantrópica con La Gota de Leche, el Comedor Infantil, el Hospicio de Huérfanos y la Cruz Roja Costarricense, ${ }^{144}$ y evidenciaba una profunda amistad tanto antes como después del régimen tinoquista, luego del cual debió Fernández salir con su esposo hacia Europa:

"Los mejores años de su vida interior los pasó María con su marido, Federico Tinoco

Granados, en la finca que tenían en Quebrada Honda [...] Recuerdo a la bella artista

139 Ibid, 302-303.

140 Alejandro Bonilla, El retrato del recuerdo y el olvido: políticas de conciliación, olvido y memorias emblemáticas de la dictadura de Federico Tinoco Granados (1917-1963) (Tesis de Maestría en Historia, Universidad de Costa Rica, 2013), 274-302; Manuel Solís, Alfonso González y Rolando Pérez, "Joaquín García Monge y Repertorio Americano: momentos de afirmación de la cultura política costarricense", en: Avances de Investigación, n. 88 (Instituto de Investigaciones Sociales, 1993).

141 Calvo, 90-111.

142 Iván Molina Jiménez, La ciencia del momento. Astrología y espiritismo en la Costa Rica de los siglos XIX y XX (Heredia, Costa Rica: EUNA, 2011), 86.

143 Acuña, La mujer costarricense a través de cuatro siglos. Tomo II, 346.

144 Ángela Acuña, La mujer costarricense a través de cuatro siglos. Tomo I (San José, Costa Rica: Imprenta Nacional, 1969), 444-453. 
pintándonos, en Quebrada Honda, a Zoyla Guardia y a mí, unas lindas bolsas de seda, con dibujos fantásticos, con el deseo de que las llenásemos de confeti, para unas fiestas capitalinas, tan lejanas ya en la memoria de los años. Éramos muy niñas y nos había llevado, la querida Mimi, a pasar una temporada en su nido enclavado en la montaña". ${ }^{145}$

"Abierta siempre al perdón, a una exquisita sensibilidad. Sabía de sobra que la vida está formada de ventajas y de cargas, de amables soluciones y de tristes realidades [...] Recuerdo que estando yo con ella en su casa de París, situada en la Avenida de la Motte Piquet, en el año 1928, le narré un sueño que tuve tan gráfico que me impresionó vivamente [...] Vi dos caminos, en líneas paralelas, sin vegetación alguna, uno más corto que el otro. Por aquel transitaba su marido, por el segundo interminable, iba María mirando el infinito [...] Se lo narré al día siguiente muy temprano. María lo interpretó en forma precisa [...] ¡El sueño se cumplió! [...] Después de sus años de apogeo científico en Francia, donde se orientó por la luz universal, por esa claridad acumulada por los sabios de todas las edades, tuvo el dolor de ver morir a su marido. ¡Grande fue su soledad!”. ${ }^{146}$

Acuña, además, aparecía muy cercana a intelectuales como Roberto Brenes Mesén, figura controversial por ser una de las cooptaciones más llamativas de la dictadura de los Tinoco y protagonista cultural del proceso de conciliación y olvido una vez derrocado el régimen; en 1912, por intermediación de Brenes Mesén, entonces subsecretario de Instrucción Pública, Acuña ingresó al colegio de varones Liceo de Costa Rica, única institución donde podía obtener un bachillerato en humanidades; luego, en 1917, como subsecretario de Educación Pública del gobierno golpista, le llevó a trabajar al Palacio Nacional en la Sección de la Junta Calificadora del Personal Docente. ${ }^{147}$ Junto con Brenes Mesén, Acuña formaba parte de la intelectualidad del Ateneo de Costa Rica, institución que igualmente debió acondicionar su pasado en el proceso conciliatorio con la dictadura, luego de haberle servido como plataforma cívica y cultural. ${ }^{148}$ Otro integrante del Ateneo fue el diplomático, escritor e historiador Ricardo Fernández Guardia, quien fuera enviado extraordinario y ministro plenipotenciario del Gobierno de Tinoco; ${ }^{149}$ a su vez, tanto Brenes Mesén como Fernández Guardia formaron parte de los círculos espiritistas y teosóficos que frecuentaban también Federico Tinoco y su esposa María Fernández, ${ }^{150}$ y las esposas de Brenes Mesén y Fernández Guardia, Ana María Carrillo y Anita Peralta integraron junto con María Fernández la Junta Directiva del Comité de Damas para socorrer a los niños belgas de la guerra, creado en marzo de $1917 .{ }^{151}$

145 Acuña, La mujer costarricense a través de cuatro siglos. Tomo I, 444-445.

146 Ibid, 445-447.

147 Calvo, 53-69; Acuña, La mujer costarricense a través de cuatro siglos. Tomo II, 350.

148 Arias Mora, Héroes melancólicos..., 270-280.

149 Jorge Francisco Sáenz Carbonell, El Canciller Fernández Guardia (San José, Costa Rica: MREC, Instituto Manuel María Peralta, 2015), 90-103.

150 Molina Jiménez, La ciencia del momento..., 51, 77-92.

151 La Prensa Libre, "La organización de las Fiestas Belgas”, 23 de marzo de 1917, 2. 
Como lo ha indicado la historiografía, la creación en Costa Rica de la Liga Feminista en 1923 tuvo como antecedente la movilización en 1919 de las educadoras y estudiantes del Colegio Superior de Señoritas contra la dictadura de los Tinoco. En su libro Acuña hizo mención de este movimiento, frente al cual la autora reconoce su heroísmo y civismo; pero admite, como "un deber de conciencia", que le unía una honda amistad con la familia Tinoco, y que, en esos momentos de protesta, ella "estaba en la Casa Presidencial". ${ }^{152}$ Tanto Acuña, nombrada presidenta de la Liga Feminista, como Esther de Mezerville, electa vicepresidenta, formaron parte de la movilización femenina en la caridad internacional de la Gran Guerra: Acuña en las actividades benéficas, muy cercana por su amistad a María Fernández de Tinoco y lejos del levantamiento docente contra la dictadura, mientras que Mezerville fue segunda secretaria del Comité de Damas por los niños belgas, aunque luego se distanció del régimen y participó de la protesta que lo derrocó. ${ }^{153}$ Esto permite inferir que la conformación oficial del feminismo en el país se benefició de la cultura política, intelectual y filantrópica de las mujeres que participaron de la movilización ante la guerra, así como de la atmósfera internacional de organizaciones y causas que en relación con ella se formaron, ${ }^{154}$ como el Comité Internacional de Mujeres pro Paz Permanente; pero en su libro, Ángela Acuña no traza este vínculo para dar una explicación histórica al origen de la Liga Feminista, y lejos de ello, su testimonio y la falta de referencias sobre las mujeres costarricenses en la Gran Guerra sugieren que, en los orígenes del feminismo, este contaba no solo con cierta diversidad social, sino también con una complejidad política que requirió participar en la depuración de un pasado autoritario incómodo y comprometedor, tal como lo hacían otras figuras, grupos e instituciones.

\section{Conclusiones}

Una de las principales hipótesis de este trabajo es que la separación de la historiografía de las mujeres con respecto a la historiografía de los efectos de la Primera Guerra Mundial radicaba en la ausencia del recuerdo de la guerra en la memoria de las mujeres o, más específicamente, del feminismo. Es posible que otros factores contribuyan a esto, como lo son la dimensión modesta de la participación femenina en ese hecho bélico - pues las experiencias directas o indirectas, nunca militares, contaban a decenas, no centenas, de mujeres con un determinado perfil de clase y una especial situación geográfica-, o la condición incipiente de una literatura o una narrativa femenina. La historiografía de

152 Acuña, La mujer costarricense a través de cuatro siglos. Tomo I, 160-161.

153 Eduardo Oconitrillo, Los Tinoco (1917-1919) (San José, Costa Rica: ECR, 1991), 161-162. También véase La Prensa Libre, "La organización de las Fiestas Belgas", 23 de marzo de 1917, 2.

154 Rinke, Im Sog der Katastrophe, 279-281. 
género y de las mujeres, cada vez que ha referido a la historia y a la biografía del feminismo sufragista ha tenido en el libro de Ángela Acuña una fuente indispensable y privilegiada, por lo cual se le ha citado con toda justicia; sin embargo, esto posiblemente haya incidido para que una temática tan fundamental para la comprensión del feminismo y del sufragismo internacional, como lo es la Gran Guerra, no haya sido contemplada dentro de la historiografía costarricense o centroamericana, por cuanto el recuerdo de Acuña, como se ha podido apreciar, tiene algunos silencios significativos que vinculan parte de los orígenes del feminismo con un pasado político comprometedor en el contexto de la guerra.

Al buscar llenar este vacío historiográfico, ¿qué es lo que se restablece en el conocimiento de la historia de las mujeres y de género, colocando en su cronología a la Primera Guerra Mundial? La experiencia de las mujeres con respecto a la guerra es, en muchos sentidos, no muy distinta a la de los hombres cuando se trataba de salir de una Europa en llamas para poder regresar al país por los medios que fueran; por el orden de los géneros, parece que la vivencia dentro del país remite a la construcción tradicional del heroísmo masculino y del sufrimiento femenino por sus hombres, fueran hijos o esposos. No obstante, como bien lo reflejaron las noticias venidas de aquel continente sobre lo acontecido en la guerra, la experiencia femenina en ella no era homogénea; de este modo, tanto pudieron algunas mujeres costarricenses agenciar su participación en el heroísmo de la enfermería de guerra al otro lado del océano, como se movilizaron otras desde su país para aliviar tanta destrucción humana.

Lo restablecido en el conocimiento histórico, en este caso, refiere a toda la experiencia acumulada en el pasado, en materia de beneficencia y de una filantropía tendiente a revalorar los roles de género, donde las mujeres se hacían un espacio y obtenían reconocimiento dando un significado social y político a la maternidad, proyectando tal experiencia en la coyuntura de la guerra y de la caridad internacional que la acompañó. Esto, a la vez, abrió un escenario hasta entonces desconocido: aquella actividad solidaria constituyó su primera proyección internacional a escala colectiva, esa participación de las mujeres costarricenses en la Gran Guerra iniciaría una cultura política determinante para la vivencia femenina de lo político a lo largo del siglo XX con sus diferentes guerras mundiales y conflictos internacionales; con esto no se trata solamente de establecer señalamientos cronológicos, pues con la proyección internacional deviene el ingreso en la circulación global de discursos, de ideas y de organizaciones, aspectos que dan forma y resonancias trasnacionales al curso de la sociedad y de los géneros. En este sentido, a la narrativa historiográfica que encuentra en la movilización femenina contra la dictadura un antecedente para la conformación de la Liga Feminista, se agrega una coyuntura menos inmediata y de cierta complejidad; en buena medida, gracias al estudio de las mujeres en la Gran Guerra se evidencia la contradicción en los orígenes del feminismo. 
Esto ocasiona que, como en la historiografía internacional, el significado de esa guerra en la performatividad política de las mujeres costarricenses igualmente oscile, generando no solo conservadurismo y silencio, sino también una apertura transformadora en donde la guerra se filtra en otras más cotidianas; con sus relatos y fotografías, el mundo de 1914 ensanchó el espectro performativo de los géneros, pues enfermeras, colaboradoras y malheridas se sumaron a un ya cambiante escenario social donde educaban, curaban y lucían cada vez más, diversificando sus espacios de reconocimiento y complejizando, a fin de cuentas, la gran guerra de las mujeres. 